\title{
Deprem Sonrası Ağır Hasarlı Bina Hasarlarının Sınıflandırılması
}

\author{
Varol Koç1,* \\ ${ }^{1}$ Ondokuz Mayıs Üniversitesi Mühendislik Fakültesi Inşaat Mühendisliği Bölümü 55139 Kurupelit, Samsun.

\section{Özet}

Bu çalışmada betonarme binalarda depremler sonrası gözlenen ağır hasar tipleri sınıflandırılıp yapısal davranışla ilişkilendirilerek incelenmiştir. Çok kapsamlı hasar çeşitleri olduğundan, özellikle sadece kolon ve kolon- kiriş birleşim hasarlarından kaynaklanan ağır hasarlar ele alınmıştır. Sinıflandırma öncelikle yapısal sistemin hasar türleri ve yapısal elemanların hasarları şeklinde yapılmıştır. Yapısal sistemin hasar türleri; 1) Üst üste yı̆̆ılma yıkımı türden hasarlar 2) Yana yığılma (Akordeon) yıkımı hasarları 3) Yana yatma hasarları 4) Düşey hiza boyunca bir bölümün çökmesi tipinde hasarlar 5) Yatayda bir bölümün çökmesi hasarları 6) Yatayda tam kat çökmesi şeklinde, yapısal elemanların hasarları da 1) Kolon düzlem dışı sıyrılması 2) Kolon uç bölgesi hasarları olarak gruplandırılmıştır. Yine yapısal eleman hasarlarından sayılabilecek kiriş ve döşeme hasarları, bu çalışmanın kapsamına dahil edilmemiştir. İncelenen hasar tipleriyle karşılaşılmaması için yapılması gerekenler özetlenmiştir.

\section{Classification of Heavily Damaged Building Damage after Earthquake}

\begin{abstract}
In this study, severe damage types in concrete buildings observed after earthquakes were classified and investigated in relation to the structural behaviors. Since the damage types are very extensive, particularly heavy damages caused by column and combination of beam-column damages were discussed. Classification is made primarily in the form of damage types of the structural system and damages of structural elements. Classification of damage types of structural system was grouped as 1) Overlap collapse related damages, 2) Lateral collapse (accordion) damages, 3) Tilting damages, 4) Failure of a part on vertical alignment type damages, 5) Failure of a part of horizontal alignment type damages and 6) Horizontal failure of entire story while the damages of structural elements were grouped as 1) Out of plane deboning of column and 2) End part damages of column. Beams and floor damages, also considered as structural system damages, are not included in the scope of this study. This study summarizes precautions needed to be taken to prevent such damages studied.
\end{abstract}

$\underline{\text { Keywords }}$

Earthquake, Structural Behavior, Column, Column - Beam Connection, Types of Damage

\section{Giriş}

Betonarme yapılarda deprem kuvvetlerine maruz kalan taşıyıcı sistem açısından kolon-kiriş birleşim bölgesi ve bu bölgenin depreme karşı davranışı son derece önemlidir. Daha önce meydana gelen yıkııı depremlerde birleşim bölgesindeki etriye yetersizlikleri, beton kalitesizlikleri ve çeşitli boyutlandırma hataları nedeniyle oluşan ani göçmeler, can kayıpları bir hayli fazla olmuştur. Deprem kuvvetlerine karşı yapı sünek davranmalı, gelen deprem kuvvetlerini başarılı bir şekilde sönümleyebilmelidir. İstenen yapının hasar görmemesi değil en azından ani olarak göçmemesidir (Büyükkaragöz 2007). Betonarme yapılarda çeşitli imalat zorlukları, projenin uygun olmayışı gibi çeşitli sebeplerden dolayı kolonlar kirişlerden daha zayıf yapılabilmekte ve ayrıca kirişlerin döşeme ile birlikte davranması sonucu tasarlanandan daha yüksek taşıma gücüne ve yatay rijitliğe sahip olması neticesinde çerçeve hasarı daha çok kolonlarda olabilmektedir. $\mathrm{Bu}$ yüzden kolonlarda oluşan kesme ve basınç hasarları sonucunda kolonlarda gevrek ve ani kırılmalar meydana gelebilir.

Çerçeve türü yapılarda deprem yükleri altında en fazla birleşim bölgelerindeki kolon ve kiriş kesitleri zorlanmaktadır. Şiddetli bir depremde yüklerin artması durumunda sözü edilen kesitlerde plastik şekil değiştirmeler ortaya çıkar. Plastik şekil değiştirmelerin başladığı kesitlerde artan yükle beraber iç kuvvetlerde önemli bir artış olmadan plastik şekil değiştirmelerin artmaya devam ettiği düşünülebilir, bu davranışa plastik mafsal davranışı da denir (eğilme momenti etkisiyle plastik şekil değiştirme yapan sünek kesitler için geçerlidir). Başka bir deyişle yapı hasar görerek enerji yutar. Plastik mafsalın normal mafsaldan farkı üzerinde sabit bir moment olmasıdır. Plastik mafsalların sayısının giderek artmasıyla taşıyıcı sistem göçme konumuna gelebilir. Buna mekanizma durumu da denir. Bu noktada 
plastik mafsalların yapı içindeki dağılımı oldukça önemlidir. Plastik mafsalların kolon kesitlerinde oluşması durumuna kolon mekanizması, kiriş kesitlerinde oluşması durumuna ise kiriş mekanizması adı verilir (Çaydemir 2012). Kolon mekanizmasında yapı az sayıda plastik mafsal oluşumuyla göçme konumuna gelir. Dolayısıyla yapı nispeten daha az enerji yutarak mekanizma haline gelir; yani yapının göçmesi için nispeten daha küçük deprem enerjisi yeterli olabilir. Kiriş mekanizmasında ise yapının göçme konumuna gelmesi için çok sayıda plastik mafsal gereklidir. Dolayısıyla yapı daha çok enerji yutarak mekanizma haline gelir; yani yapının göçmesi için daha büyük deprem enerjisi gerekir. Plastik mafsallarının yapının bir kat kolonlarının bir kısmında sadece alt ve/veya üst uçlarında oluşması sonucunda bile az sayıda plastik mafsal oluşumuyla yapı göçme konumuna gelecek ve can kaybı olabilecektir. Bunun engellenmesi ve yapının plastik mafsallarının kiriş uçlarında oluşacak şekilde tasarlanması gerekir. Bunun için de kolonların kirişlerden daha güçlü yapılması şarttır.

Betonarme çerçeveli yapıların gereken sünekliğe ulaşamamasında süneklik için çok gerekli olan kuvvetli kolon zayıf kiriş davranışı yerine kuvvetli kiriş zayıf kolon düzenlemesi oluşturulması, zayıf kolon olarak nitelendirilebilir. Bu tür binalarda kolon kesit boyutları en azından kiriş boyutlarına oranla küçük seçildiğinden kolonlar oldukça narindir. Kiriş kesitleri ise tam tersine gereğinden yüksek yapılmıştır. Bunun bir nedeni kiriş boyutlarının pencere boşluklarına uydurulması çabası, diğer nedeni de kolon kalınlığının duvar kalınlığını geçmemesine çalışılmasıdır.

Betonarme yapı hasarları öneminden ve bazen tip ve benzer proje uygulamasına gidilmesinden dolayı kamuya ait hastane ve okul binaları ile özel kesim binaları olarak ele alınabilir. Her iki kesim binalarındaki hasarların büyük bir bölümü aşikâr fiziksel tasarım hataları, projelendirme kusurları ile yapım yetersizliğinden kaynaklanmaktadır. Betonarme sistemlerde rastlanabilecek yirmiyi aşkın kusura karşın ancak sadece birkaç kusur ve hatanın mevcudiyeti tam ya da kısmi göçmeye yol açmamaktadır (Karaşin 2003).

Deprem sonrası yıkılan ve ağır hasar gören yapılar üzerinde yapılan incelemeler sonucu bu yapılardaki ortak kusurlardan bir tanesinin de kullanılan agrega ve betonun standartların öngördüğü koşulları sağlamıyor olmasıdır. Örneğin Bingöl'de gözlenen çok iri boyutlu çakıl ve taşlı geleneksel taşra betonları ile nadir de olsa bazen gerekli beton dayanımı tutturulabilmiştir. İnşaat mühendisleri odası Antalya şubesince 1 Mayıs 2003 Depreminden sonra Bingöl'de değişik yapılardan alınan beton karot örnekleri üzerinde yapılan beton basınç dayanım deneylerinden elde edilen ortalama beton silindir basınç dayanımı $95 \pm 47 \mathrm{~kg} / \mathrm{cm}^{2}$ olarak bulunmuştur (Bayülke vd. 2011). Beton kalitesi dışında düğüm noktalarını doldurmayan iri agrega ve taşlar göçme ve ağır hasarların bir başka sebebidir (Karaşin 2003). Deprem sonrası görülen kolon ve kolon- kiriş birleşimi hasarları aşağıdaki şekilde sınıflandırarak incelenebilir:

\section{Yapısal Sistem Hasar Türleri}

\section{1. Üst Üste YığıIma Yıkımı Türünden Hasarlar}

Genel Göçme de denilebilecek, katların üst üste yığılması şeklindeki yıkımlar, şüphesiz en ciddi hasar çeşididir. Deprem etkisindeki önemli yapıların boyutlandırılması aşamalarında kalıcı şekil değiştirmeler yapmasına izin verilse de toptan göçmeye karşı önlem alınması yani kalıcı şekil değiştirmelerin hangi nedenle olursa olsun bölgesel göçme odakları oluşturacak biçimde birikmeleriyle kat mekanizması oluşturması engellenmelidir. Bunun kolay yollarından biri kuvvetli kolon zayıf kiriş düşüncesinin boyutlandırmaya esas alınmasıdır. Bu düşünce benimsenmeden yapılacak 4-6 katlı, açıklıkları kat yüksekliğinden büyük bina türü yapıların boyutlandırılmasında tersine sonuçlara varmayı engelleyecek yani kuvvetli kiriş zayıf kolon sonucuna varmayı önleyecek bir çözümün kendiliğinden oluşması beklenmez. Aksi halin doğal sonucu olarak yapı yatay rijitliği azalır, doğal titreşim periyodu yükselir ve yapı kayma tipi davranış gösterir ki, katlar arası yatay yer değiştirme farkları en alt katlarda çok, üst katlarda onlara göre az olur. Bu durum, yatay yer değiştirmelerin artması halinde zemin katta eksenel kuvvetlerin ikinci mertebe etkilerini de artırıcı yöndedir (İTÜ 1992). Taşıyıcı elemanların yanal yüklere karşı (deprem yükü) gerekli olan dirençliliği gösterememesi ve kolon kiriş bağlantı noktalarından kopması ya da kırılması sonucu oluşan bu yıkımlara, "pancake" tabir edilen katların üst üste yığılması şeklinde bütünüyle göçmeler de denmektedir. Bu durumun oluşmasında taşıyıcı sistemin yetersiz ve hatalı donatılara sahip olmasının yanında yatayda deprem yüklerine karşı dirençliliği arttıracak olan perde duvar elemanlarının olmaması, kirişlerin boyutlarının gereğinden daha fazla olması ya da kolon boyutlarının gereğinden daha küçük olması nedeniyle zayıf kolon-güçlü kiriş durumunun ortaya çıkması ve kolonların kirişler tarafından deprem anında hasara uğratılması tipik nedenler olarak sayılabilir (Karancı vd. 2011).

1992 Erzincan depremi sonrası görülen Şekil 1'deki yıkımda, tüm bu sayılan etkenlerin yanında, kolonlarda sarılma bölgesi donatılarının yetersizliği ve kolon boyuna donatılarının burkulması da etken olmuştur. Depremden sonra kolonların tümüyle ezilip dağıldığı ve döşemelerin üst üste yığıldığ 1 yıkımlarda, hasarın öncelikle kolonlarda toplanmış olduğu düşünülmüştür (İTÜ 1992). Şekil 2'deki, bodrumuyla birlikte toplam yedi katlı olan binanın da, zemin kat kolonlarının hepsi ezilmiş bina bir kat kısalmış ve bu katta 80-100 cm yatay ötelenme yaparak toptan göçmüştür. Erzincan depreminde, zemin ya da birinci katta rölatif yer değiştirmenin çok büyük olduğu başka bazı örneklerle de karşılaşılmıştır. Birçok birleşimde güçlü kiriş- zayıf kolon davranışının ortaya çıktığı görülmüştür (İTÜ 1992).

Büyük Marmara depremi sonrasına ait Şekil 3'deki binada da kolonlar kirişlerden daha zayıf olduğundan zayıf kolonlar üst katlarda kırılarak göçmüştür. Deprem kuvvetlerinde oluşan enerji, kolon- kiriş birleşmelerinde, yetersiz donatı ve yetersiz kesit nedeniyle tüketilemediğinden buralarda kırılma ve göçmeler meydana gelmiştir. Zemin katta kısmen daha güçlü geniş kolon/ perdeler olduğundan zemin kat yıkılmamıştır. 
Şekil 4, 5, 6, 7'de verilen okul pansiyonu binası hasarı da, 1 Mayıs 2003 Çimenli (Bingöl) depremi sonrasında oluşmuştur. Söz konusu depremde, 1971 depremi ölçüsünde yıkım meydana gelmemesine rağmen 177 kişi yaşamını yitirmiş, 520 kişi yaralanmış, 82 yapı tümüyle yıkılmış, 1602 bina ise ağır hasara uğramıştır. Değişik yerleşim alanları içinde en büyük can kaybı ise Çeltiksuyu Yatılı İlköğretim Bölge Okulu (YİBO) yatakhane binasında meydana gelmiştir. Bingöl il merkezinde meydana gelen hasarlarla Çeltiksuyu'nda YİBO'nun yatakhane bloğunun yıkılması zemin koşullarına değil tamamen projelendirme hataları ile bina kalitesinin düşüklüğüne bağlıdır (Dirlik vd. 2003 ). 84 çocuğun ölümüyle sonuçlanan facianın sebebini sadece işçilik hataları, malzeme ve beton kalitesi, müteahhit insafi gibi gerekçelere dayandırmak yeterli değildir. Tip projelendirmedeki taşıyıcı sistemin acemice seçimi ve taşıyıcı çerçeve elemanlarının boyutlandırmasındaki özensizlik, farklı bölgelerde yapılan birçok binayı birden riske sokmaktadır. Yatakhane bloğundaki özet görüntülerde görülebileceği gibi kolon-kiriş ön seçimindeki uygunsuzluk aşikardır. Kirişlerin kısmi konsol olarak çalıştırılmış olması yatay deplasmanın sınırlandırılamamasında önemli bir role sahip olmuştur. Ayrıca kirişlerin kolonlardan çok daha güçlü bir şekilde boyutlandırılması ile mafsallaşmanın kiriş yerine kolonlarda oluşmasına yol açılmıştır. Bu durumlar göçmenin ana etkenleri olarak değerlendirilebilir. (Karaşin ve Karaesmen 2005) Nitekim bu okul ile aynı projeye sahip Kaleönü YİBO derslik binasında da benzer hasarların oluşması bu okulların projelerinin tekrar gözden geçirilmesi gerektiğini gözler önüne sermektedir (Şekil 8) (Dirlik vd. 2003). Kaleönü İlköğretim Okulu hasarını gösteren Şekil 8'deki hasar, yatayda bir bölümün çökmesi olarak sınıflandırılabilecek bir hasar tipiyle sınırlı kalabilse de, Çeltiksuyu YİBO pansiyonundaki hatalar bu okul için de geçerlidir. Zeminin nispeten daha iyi bir davranış göstermesi ve beton- donatı malzeme ve işçiliğinin bir miktar daha iyi olması sayesinde bu yapıda Çeltiksuyu YİBO pansiyonundaki gibi tam göçme oluşmamıştır.

Yine Büyük Marmara depremi sonrasına ait Şekil 9'daki binada da kolonlarda meydana gelen mafsallaşma sonucu tüm katlar üst üste yığılarak çökmüştür. Asmolen döşeme sistemine sahip bu yapıda, yatay ötelenmeler daha fazla olacağından, bu yatay ötelenmeyi karşılamak için her iki yönde perde kolonlar yerleştirilmesi gerekmekteydi. Şekil 10'daki yapıda ise, normal katların aksine giriş katları işyeri olması sebebiyle zemin kat yüksek tutulmuştur. Zemin katta bölme duvar yapılmamasının da etkisiyle ani rijitlik değişimleri kendini göstermiş, yapıda aşırı yanal yer değiştirme sonucu oluşan ikinci mertebe momentleri tam yıkıma neden olmuştur (Karaşin ve Karaesmen 2005). Şekil $11,12,13,14,15$ 'de, güçlü kiriş- zayıf kolon birleşimi, perde duvar kullanılmaması ve donatı- beton malzeme- işçilik kalitesizliği, yapıların üst üste yığılma türü yıkımına neden olmuştur. Şekil 16'daki yapıda da zayıf kolon ve yapının taşıyıcı sistemindeki yetersizlikler ile meydana gelen ağır hasarlar görülmektedir. Şekil 17'de, 3 Şubat 2002 Çay (Afyon) Depremi sonrası, Çay sanayi sitesindeki, tümüyle yıkılmış tek katlı betonarme yapılardan birisinin yakın görünümü verilmiştir. Bu yapılarda kolonların narin ve yüksek oluşu, bölme duvar desteğinin özellikle cephelerde olmaması, kirişlerin güçlü oluşu ve malzeme- işçilik kalitesizlikleri ile birlikte, sanayi sitesinin zemininin de alüvyonlu olması yapıların çoğunun tam yıkıma uğramasına neden olmuştur.

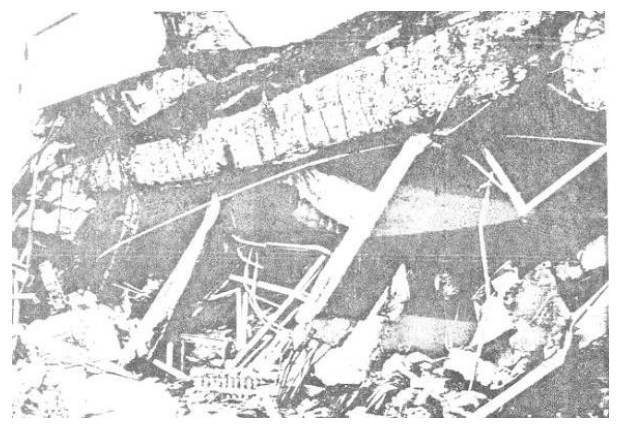

Şekil 1: Tam yıkım örneği (1992 Erzincan)

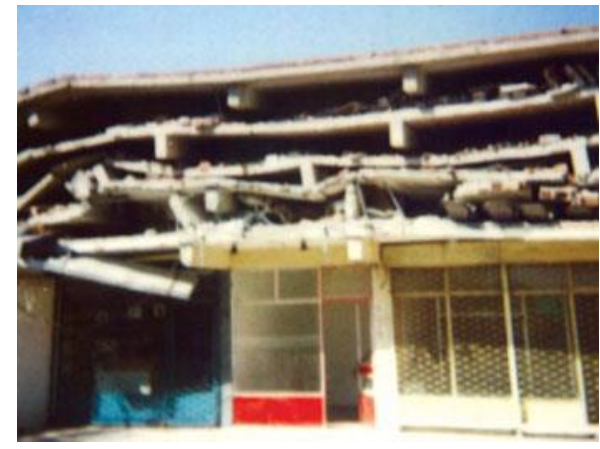

Şekil 3: Katların üst üste yığılması örneği (1999 Marmara)

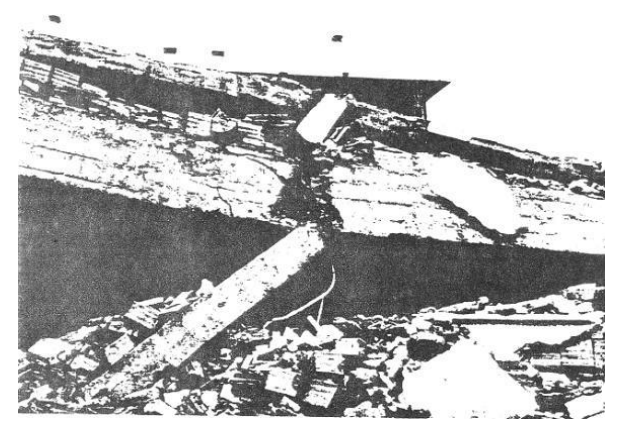

Şekil 2: Tam yıkım örneği (1992 Erzincan)

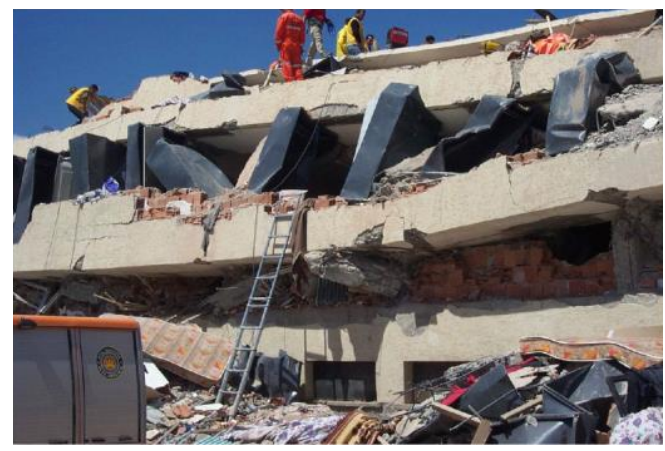

Şekil 4: Çeltiksuyu YỉBO pansiyonu (2003 Bingöl)(Kalafat vd. 2003) 


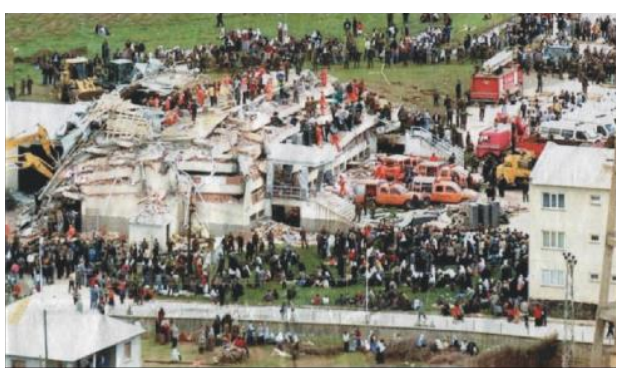

Şekil 5: Çeltiksuyu Yatılı İlköğretim Bölge Okulu pansiyonunun deprem sonrası kurtarma çalışmaları sırasındaki görünümü (Akşam Gazetesi) (Dirlik vd. 2003)

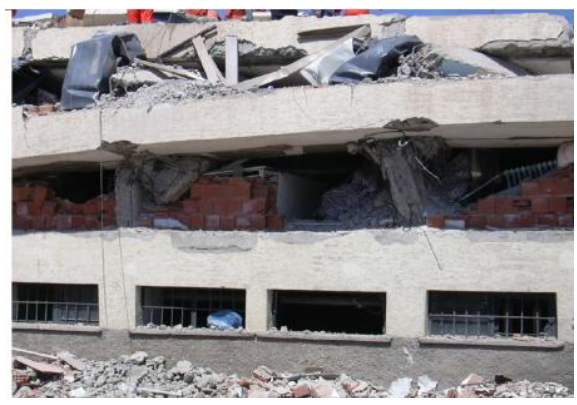

Şekil 7: Çeltiksuyu YiBO Pansiyonu (Karaşin ve Karaesmen 2005)

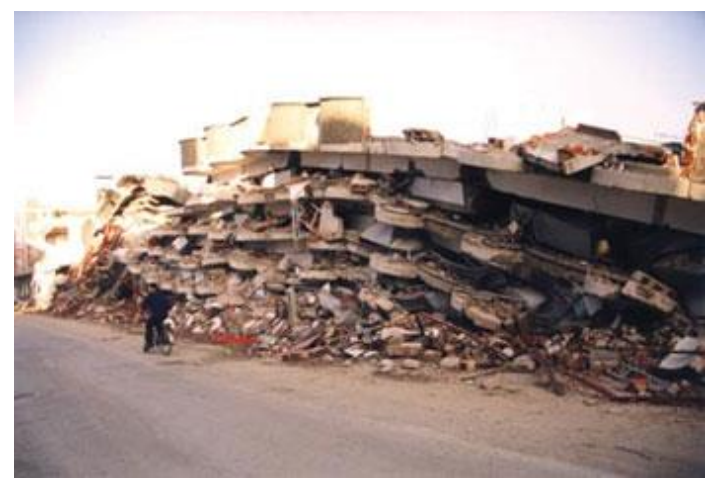

Şekil 9: Üst üste yığılma yıkımı (1999 Marmara)

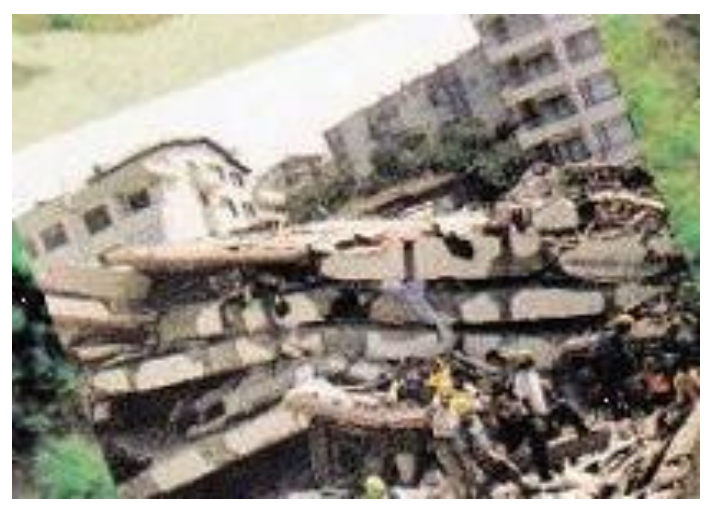

Şekil 11: Üst üste yığılma yıkımı (1999 Marmara)

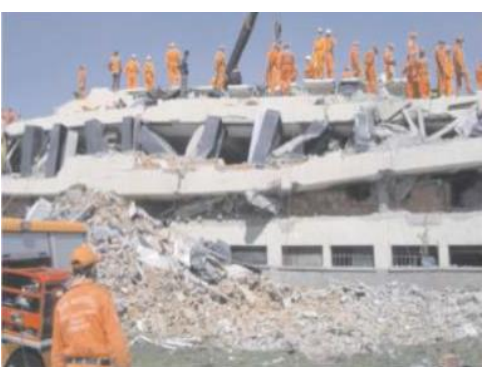

Şekil 6: Çeltiksuyu YIBBO Pansiyonu

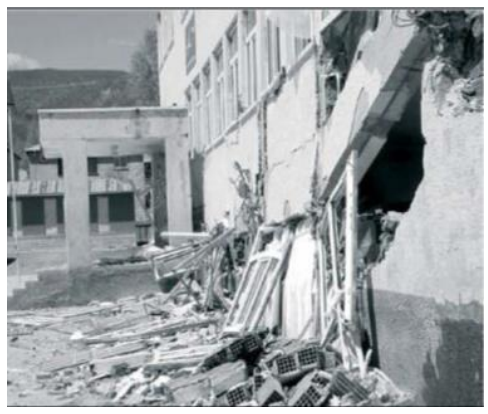

Şekil 8: Kaleönü Illköğretim Okulu (2003 Bingöl)

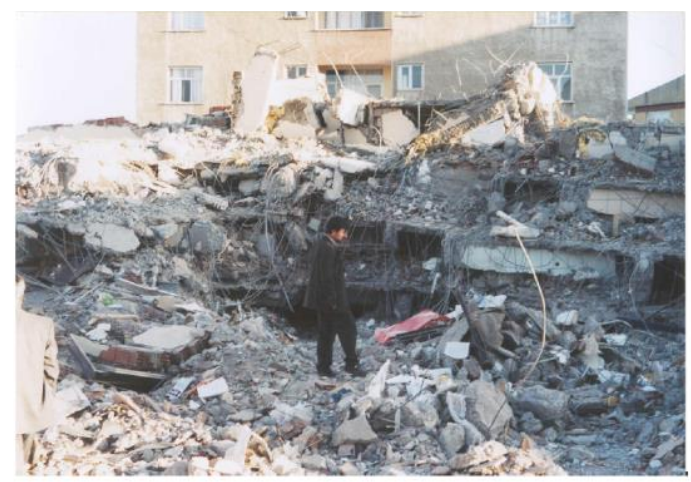

Şekil 10: Yanal Rijitliğin Azaltılması ve Kolon Kiriş Çözüşmesine Bağlı Tam Göçme (2003 Bingöl) (Karaşin ve Karaesmen 2005)

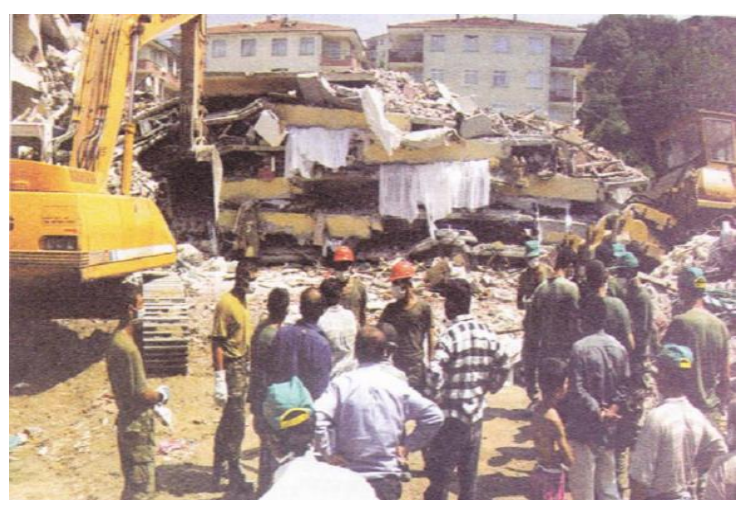

Şekil 12: Üst üste yığılma yıkımı (1999 Marmara) 


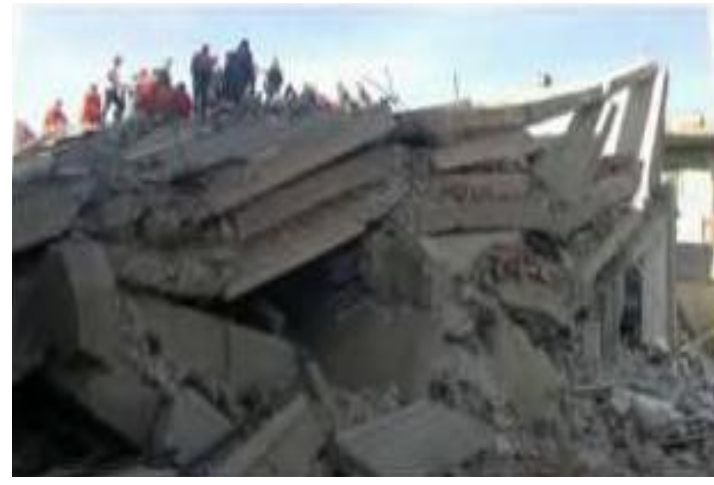

Şekil 13: Üst üste yığılma yıkımı (2011 Van)(Nurlu 2012)

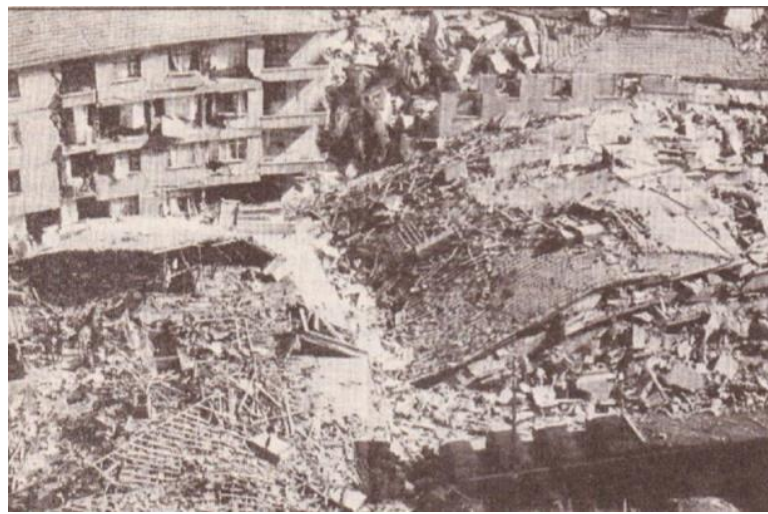

Şekil 15: Üst üste yığılma yıkımı (1999 Marmara) (Nurlu 2012).

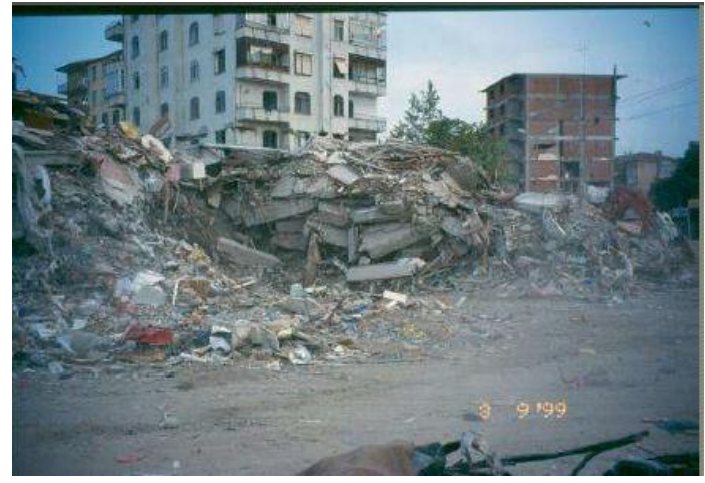

Şekil 14: Üst üste yığılma yıkımı (1999 Marmara) (Akıncıtürk 2003)

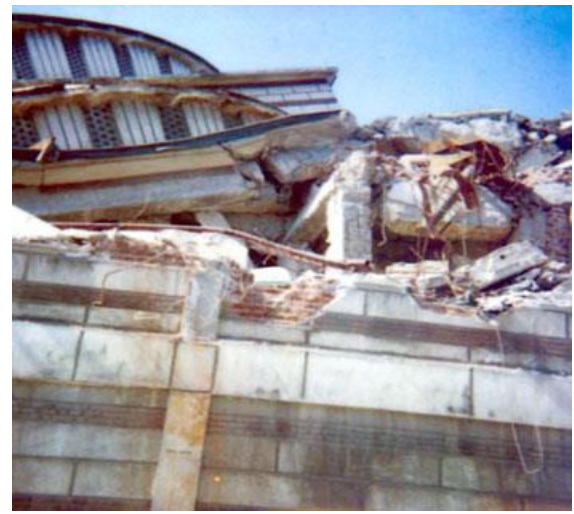

Şekil 16: Üst üste yığılma yıkımı (1999 Marmara).

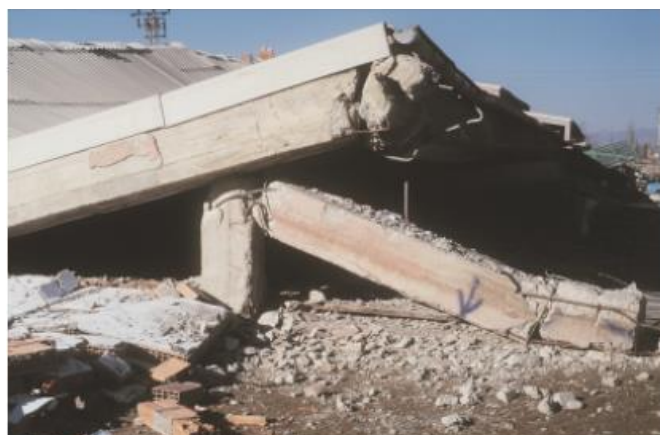

Şekil 17: Çay sanayi sitesindeki, tümüyle yıkılmış tek katıı betonarme yapılardan birisinin yakın görünümü (2002 Afyon) (Koçyiğit vd. 2002).

\subsection{Yana Yığııma (Akordeon) Yıkımı Hasarları}

Şekil 18-28'de farklı depremler sonrası görülen benzer yıkımlar sunulmuştur. Yana yı̆̆ılma (Akordeon) yıkımı hasarları diye sınıflandırabileceğimiz bu hasarın temel nedeni plastik mafsallaşmanın kolonlarda oluşması sonucu (Kuvvetli kiriş zayıf kolon yapılması, etriye sıklaştırılmasına özen gösterilmemesi, beton kalitesizliği) sistemin yana göçme mekanizmasına ulaşmasıdır. Bu binaların çoğunda, zayıf kolonla aynı etkiyi doğurabilecek kat çıkmalarının, konsol kiriş- döşemelere taşıtılmış olması ve geniş ve uzun balkonların yapılmış olması da yıkımı kolaylaştırmıştır. Yapılar, hem sünek davranışı sağlayabilecek donatı detaylandırması ve beton malzeme kalitesinden yoksun olup hem de rijitliği sağlayıcı düzgün perde duvar konumlamalarına sahip olmadıklarından, aşırı yatay ötelenmelere uğrayıp mod-1 hareketini tamamlayamadan yıkıma uğramışlardır. 


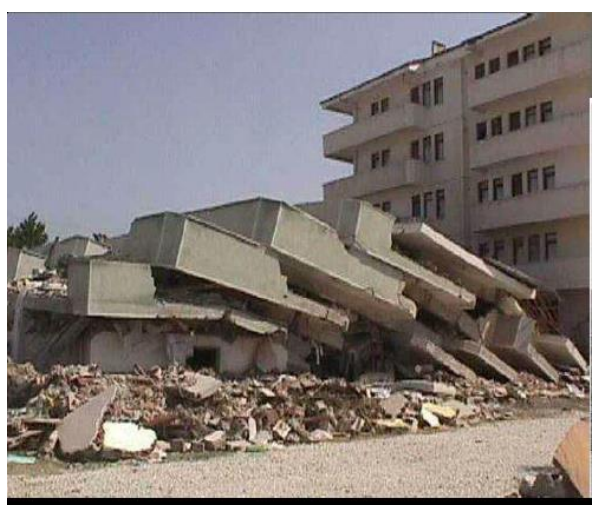

Şekil 18: Yana yığılma yıkımı (1999 Marmara) (Akıncıtürk 2003)

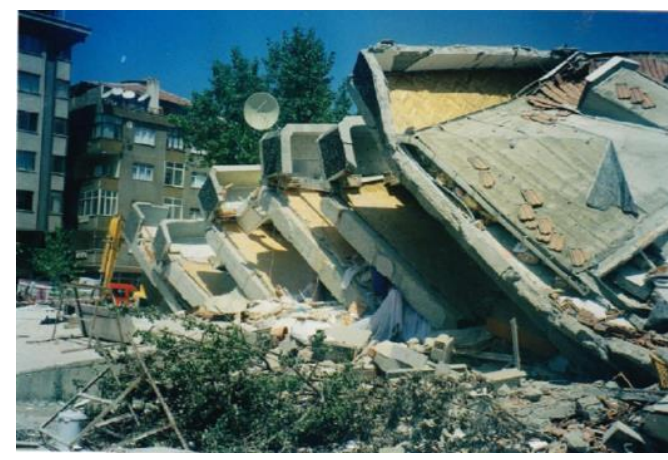

Şekil 20: Yana yığııma yıkımı (1999 Marmara)

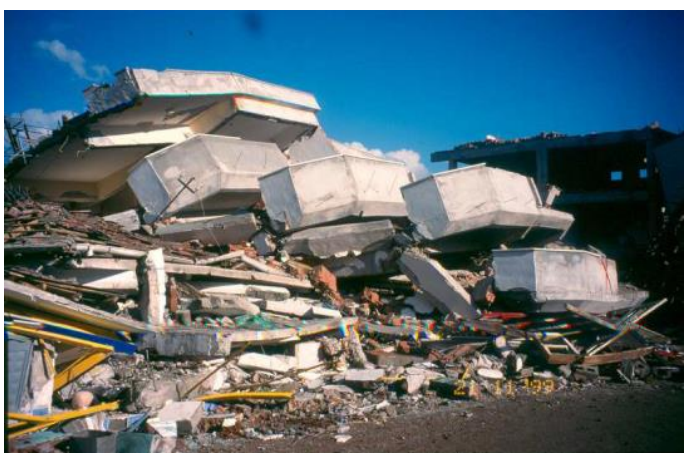

Şekil 22: Yana yığılma yıkımı (1999 Marmara) (Akıncıtürk 2003)

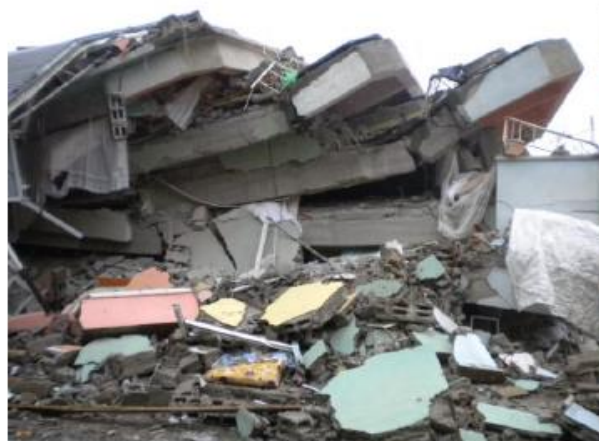

Şekil 24: Yana yığılma yıkımı (2011 Van) (Alan vd. 2011)

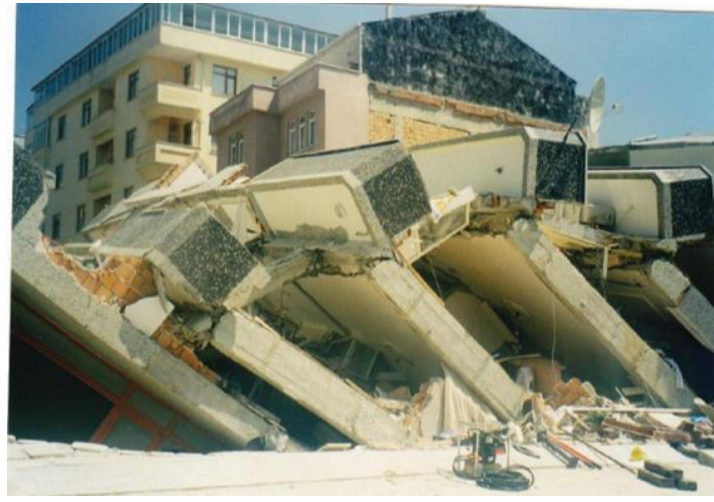

Şekil 19:Yana yığııma yıkımına uğrayan Kocaeli’nde bir bina (1999 Marmara)

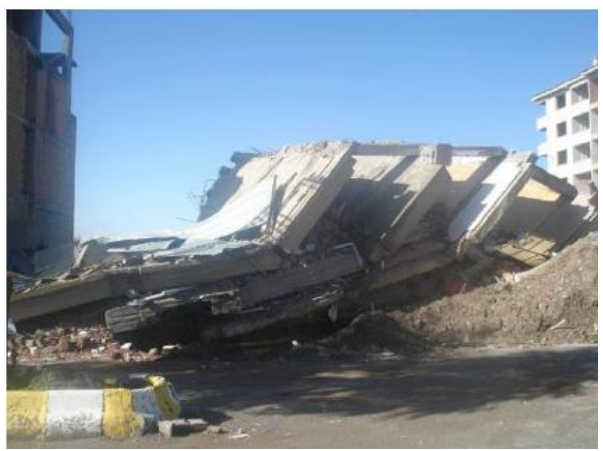

Şekil 21: Yana yığılma yıkımı (2011 Van) (Güney 2011)

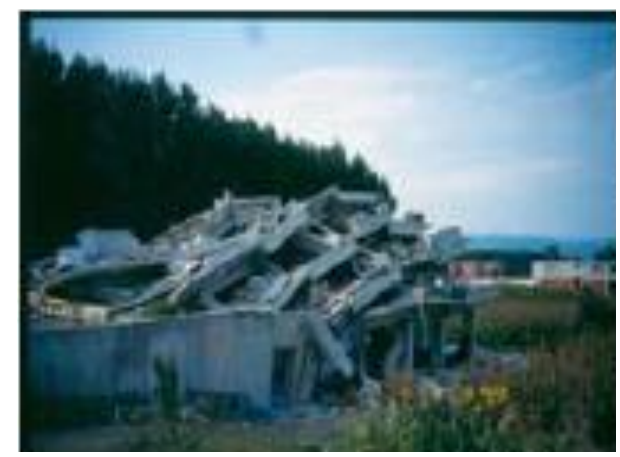

Şekil 23: Yana yığılma yıkımı (1999 Marmara) (Akıncıtürk 2003)

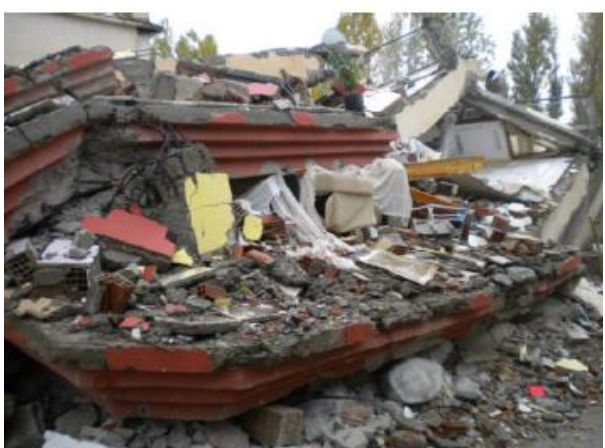

Şekil 25: Yana yığılma yıkımı (2011 Van) (Alan vd. 2011) 


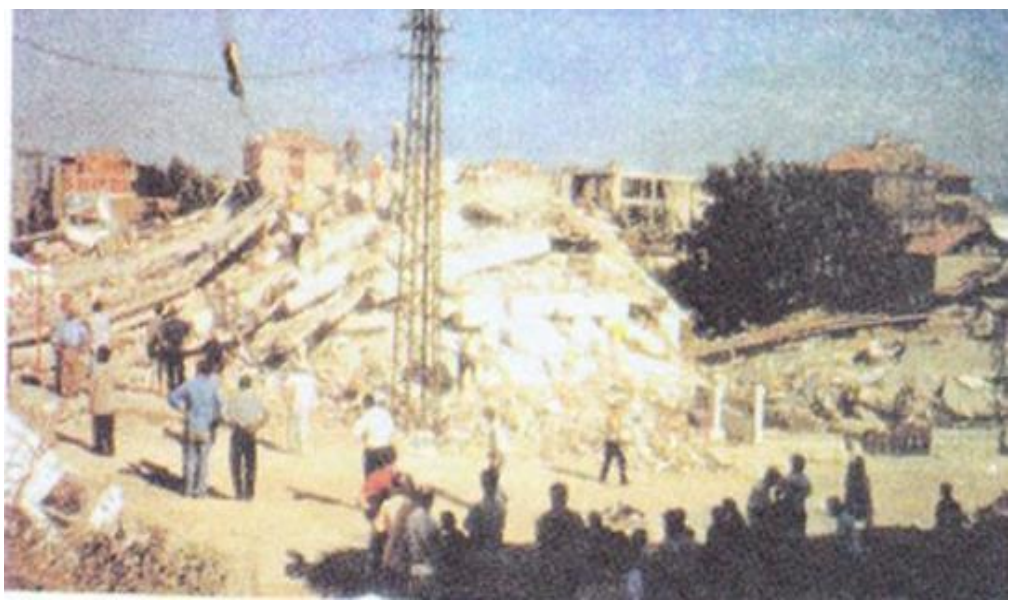

Şekil 26: Düzce'de bir özel hastanede yana yığılma yıkımı (1999 Düzce)

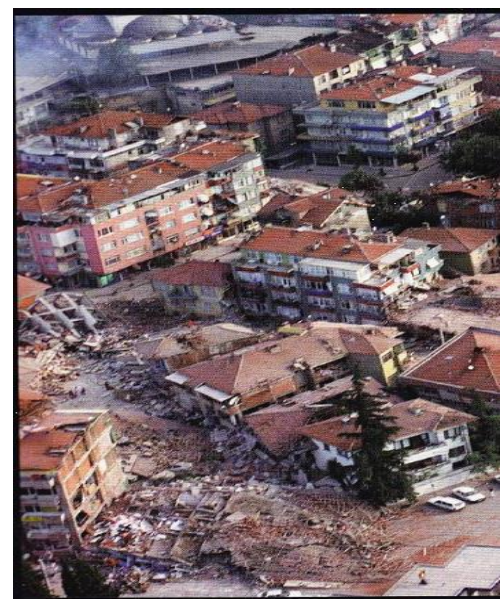

Şekil 27: Yana yığılma yıkımı (1999 Marmara)

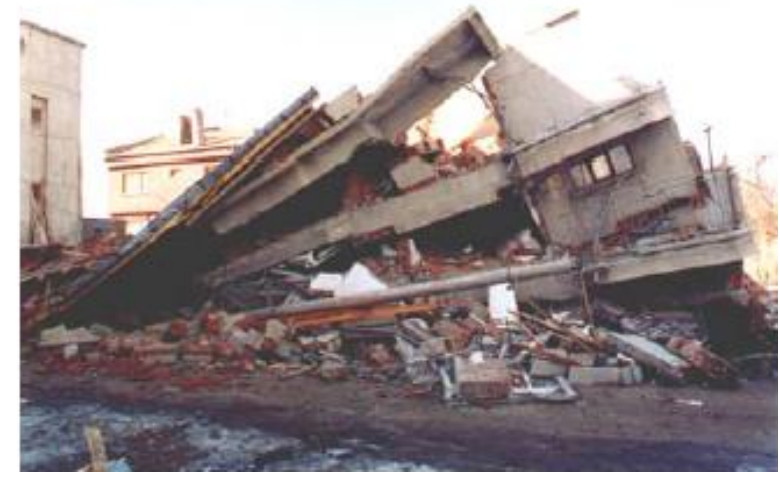

Şekil 28: Yana yığılma yıkımı (2011 Van) (Nurlu 2012)

\subsection{Yana Yatma Hasarları}

$\mathrm{Bu}$ başlık altında incelenecek hasarlar, daha önceki iki başlıkta incelenen yıkım türleri ile aynı nedenlerden dolayı oluşan, ancak bahsedilen kusurların belki nispeten daha az seviyede olmaları, zemin davranışının ve malzeme-işçilik kalitesinin göreli olarak biraz daha düzgün olması, proje hatalarının daha az hasara yönelik sonuçlar doğurması, bitişik yapıların çekiçleme etkisi gibi olumsuz bir etkileşimde bulunmasının yanında, aynı zamanda bazen yapının tamamen yıkımına engel olabilecek seviyede destekte bulunabilmeleri vb. etkenlerle, tam yıkıma uğramayan yapılara aittir. Ancak bu bölüme özellikle Şekil 29, 30, 31'de görülen ve tamamen ya da kısmen yıkıma uğramış 3 yapı hasarı örneğiyle başlamak uygun olacaktır. Zira bu yapılarda çalışmanın başından beri bahsedilen nedenlerin etkisiyle yana doğru yıkımlar gerçekleşmiştir. Tüm deprem sonrası incelemelerde görülen en önemli hataların şu an için Ülkemizdeki en son büyük deprem denilebilecek Van depremlerinde de aynen görülmüş olması üzücü bir durumdur. Van depremleri sonrasında çoğunlukla rastlanan tasarım hatalarından biri de, bu çalışmada özellikle üzerinde durulan, kirişlerin kolonlardan güçlü olması hatasıdır. Yıkılan hemen her binada plastik mafsallar kolonlarda oluşmuş, bu nedenle de binalar ağır hasar almış veya yıkılmıştır (Şekil 31) (Güney 2011). Şekil 32, 33 ve 34'de, bahsedilen nedenlerden dolayı tam yıkım oluşmamış, yana yatma hasarları kendini göstermiştir. Ülkemiz yapı stokunda bu tarz hasarlara uğramaya aday ne yazık ki çok sayıda bina vardır. Örneğin Urfa'da bir binada kolon kesitlerinin açıç̧a yetersiz olduğu, Şekil 35'den görülmektedir. Bu binada kolonlar çok narin ve asma tavan ek olarak yapılmıştır. Resimde görülen kat zemin kattır ve lokanta olarak kullanılmaktadır. Bu katın üzerinde 5 kat daha bulunmaktadır. Ayrıca bu bina 25-30 yıllık olup kesitler şu anki TS-500 şartlarına uymamaktadır. Şanlıurfa'daki mevcut eski binaların pek çoğunda bu şekilde kiriş ve kolon kesitlerinin yetersiz olduğu, yapıların TS 500 madde 7.3 ve 7.4'e uyması gerektiği belirtilmiştir (Gümüşcü vd. 2004). 


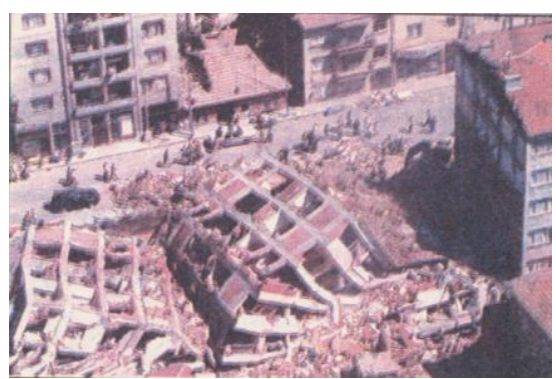

Şekil 29: Yana yığılma yıkımı (1999 Marmara)

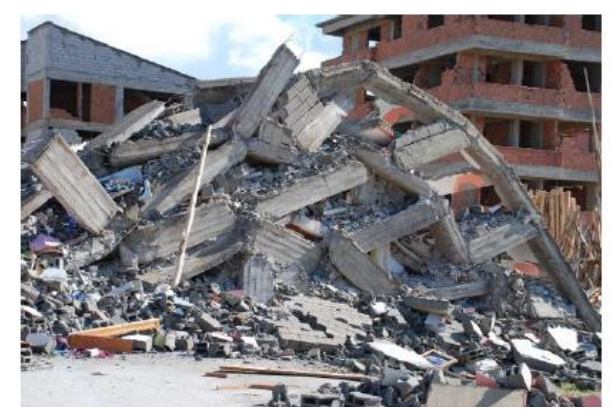

Şekil 31: Kuvvetli kiriş- zayıf kolon sonucu yana yığıIma yıkımı (2011 Van) (Güney 2011)

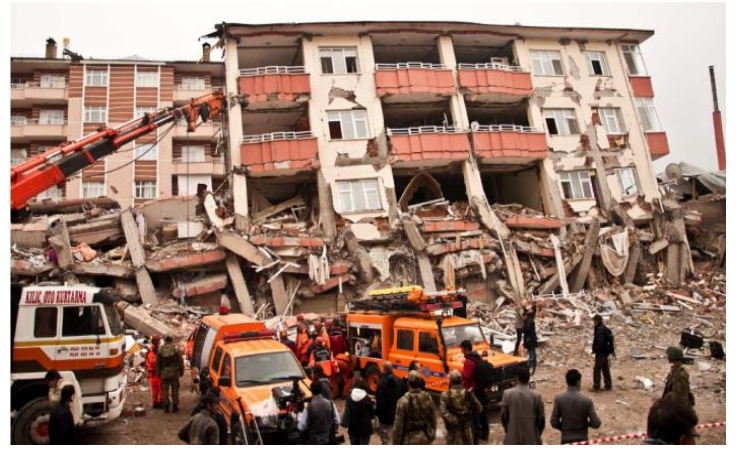

Şekil 33: Yatayda bir bölümün çökmesi ile yana yatma hasarı (2011 Van) (Güney 2011).

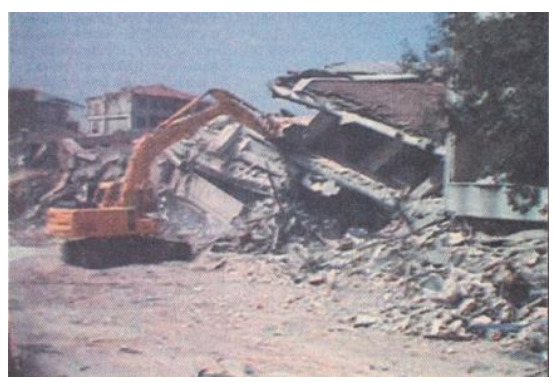

Şekil 30: Yana yatma-yığıIma hasarı (1999 Marmara)

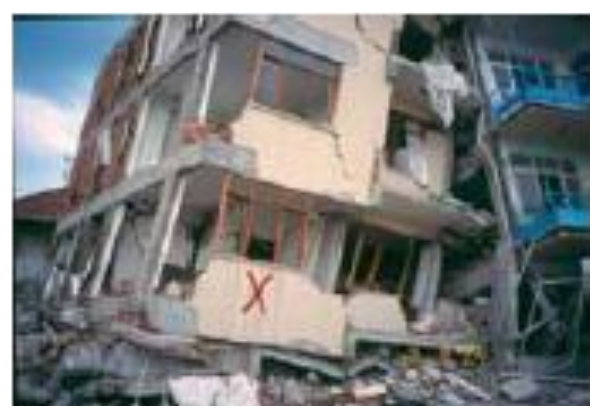

Şekil 32: Yatayda bir bölümün çökmesi ile yana yatma hasarı (1999 Marmara) (Akıncıtürk 2003)

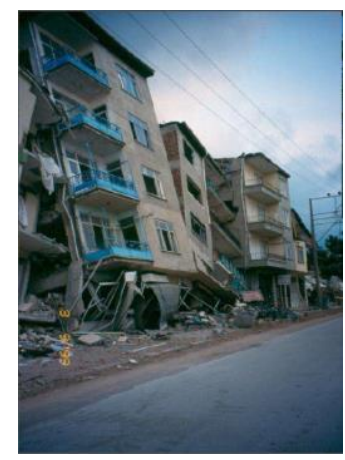

Şekil 34: Yana yatma hasarları (1999 Marmara) (Akıncıtürk 2003).

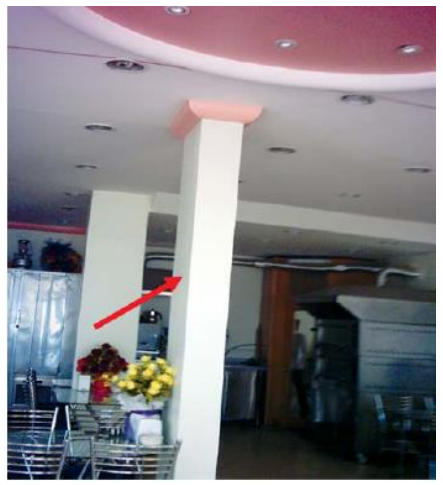

Şekil 35: Urfa'da olası bir depremde ağır hasar görmeye aday bir binanın zemin katı (Gümüşcü vd. 2004). 


\subsection{Düşey Hiza Boyunca Bir Bölümün Çökmesi Tipinde Hasarlar}

Bu hasar tipinde, sistem burulmasının da bahsedilen tüm nedenlerle birlikte etken olarak görülmesi sonucu, yapı, hemen hemen tüm katlarda, aynı bölgeden göçmeye ya da ağır hasara uğramaya meyletmektedir. Özellikle zemin kat köşe kolonunda oluşan mafsallaşma ya da düzlem dışına çıkma nedeniyle, zincirleme olarak üst katlardan alt katlara doğru o bölgede yıkım kaçınılmaz olmakta, döşeme eğilme kapasitelerinin yüksekliği ile bazen komşu bölgelere bu hasar daha az şiddetle sirayet edebilmekte ve yapı kısmen ayakta kalabilmektedir. Hasarlı bölüm, genelde, burulmanın da etkisiyle, aynı zamanda 4 yönde kiriş desteğinden de mahrum kalan köşe kolonları civarında oluşmaktadır. Dolayısıyla özellikle yapı köşe bölgelerinde tasarımdan imalata tüm kurallara sıkı sıkıya riayet etmenin önemi büyüktür. Bu yapılmaz ve aksine güçlü kiriş-zayıf kolon, narin yüksek kolon, bölme duvar desteğinin kaldırılması, kolon etriyelerinin sıklaştırılmaması, beton yerleşim ve kalitesine dikkat edilmemesi gibi hatalar bu bölgelerde yoğunlaştırılmış olursa ve sistem bütününde de yatay yükler altında oluşabilecek burulma etkilerini azaltıcı düşey rijit taşıyıcı dağılımına dikkat edilmezse, Şekil 36 ve 37'de özetlenen hasarlar kaçınılmaz olmaktadır.

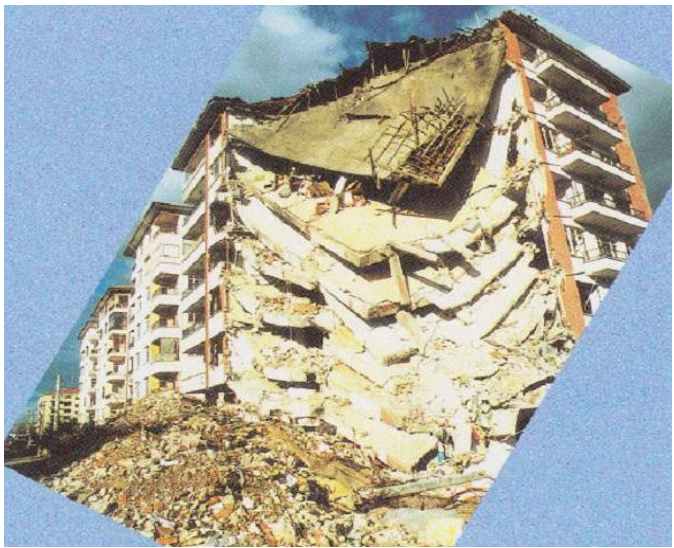

Şekil 36: Düşeyde bir bölümün çökmesi hasarı (1999 Marmara)

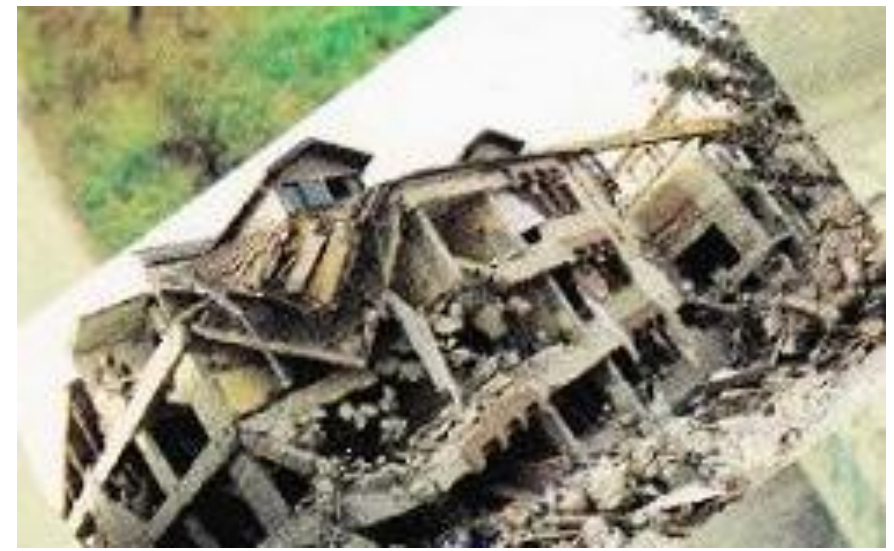

Şekil 37: Düşeyde bir bölümün çökmesi hasarı (1999 Marmara)

\subsection{Yatayda Bir Bölümün Çökmesi Hasarı}

Bir betonarme yapının döşemeleri birbirine yapışacak şekilde yıkılması tek bir kusurun kendini göstermesiyle olamaz. Bir binayı mutlak yıkıma götüren, birçok kusurun olumsuz etkilerinin aynı anda ortaya çıkmasıdır. 1992 Erzincan depreminden, bu tip hasara örnek olarak, Şekil 38'de görülen, konut tipinde olmakla birlikte kamu görevi üstlenmek üzere kiralanmış binada mekanizma durumunun birinci katta ortaya çıkması verilebilir (İTÜ 1992). Şekil 39'da verilen ve 1999 Büyük Marmara depreminden sonra Yalova'da çekilmiş fotoğrafta ise, ön tarafinda bir katlık bir çökme gözlenen binanın resmin sağ ve sol tarafında görülen ve arkada görünmeyen kısımlarının neredeyse hasarsız olarak durduğu görülmektedir. Köşe kolonuyla beraber muhtemelen bir iki kolonun dayanım yetersizliğinden oluşan bu hasar görüldüğü gibi binanın tamamen yıkılmasına yetmemiştir. Şekil 40'da sunulan yatayda kısmi göçme hasarında ise yapı kolonlarının çok narin olduğu, özellikle bir yöndeki kesit boyutunun yönetmeliğin minimum boyut koşulunu bile sağlamadığı, kirişlerin kolonlardan çok güçlü olduğu, bölme duvarı desteğinin yetersiz olduğu görülmektedir. 3 Şubat 2002 Afyon depremi sonrası, Bolvadin yolu üzerinde, mühendislik hizmeti almamış, denetimden uzak bir biçimde inşa edilmiş yapılardan birkaçı Şekil 41, 42'de görülmektedir. Hasarlı kolonlar, benzer binaların bazılarında dış, bazılarında iç kolonlar olmamak üzere farklılık göstermektedirler. Resimdeki soldan ikinci binanın birinci katının odun deposu olarak kullanılması sonucu, bina odunların üstüne oturarak yıkılmaktan kurtulmuştur. Benzer hatalara sahip diğer binada ise yine benzeri bir nedenle plastik malzemeler üzerine oturarak olası daha kötü bir durumdan tesadüfen kurtulunmuştur. Binalarda oluşmuş hasarlar tamamen yapısal kusurlardan ileri gelmekte olup zemin sıvılaşması etkisi yoktur (Damcı vd. 2002). Bir yapının emniyetli olabilmesi için yüzlerce parametrenin göz önüne alınarak davranışının belirlenmesi yani doğru bir analiz ve doğru bir tasarım yapılması (tasarımda mühendislik hizmeti alınması) gerekmektedir. Günümüzde bazı varsayımlarla basitleştirilmiş formüllerden yalnızca global bir fikir edinmek amacıyla yararlanılabilir. Ancak gerçek tasarım esnasında varsayımları minimuma indirerek tüm detayları olabildiğince göz önüne almak gerekmektedir. Bina davranışı detaylı analizler sonucunda belirlenmeli ve davranış bilgisiyle binalar projelendirilmelidir (Damc1 vd. 2002). 


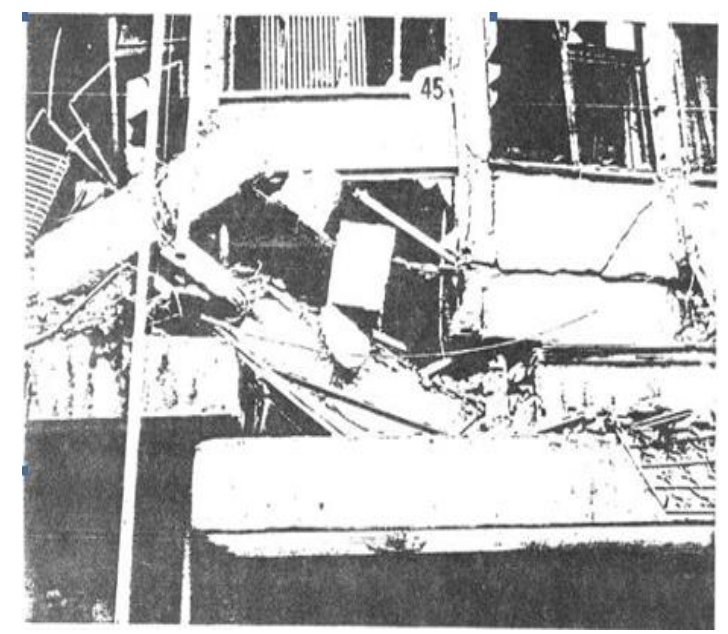

Şekil 38: Kısmi kat çökmesi örneği (1992

Erzincan) (ITÜ 1992).

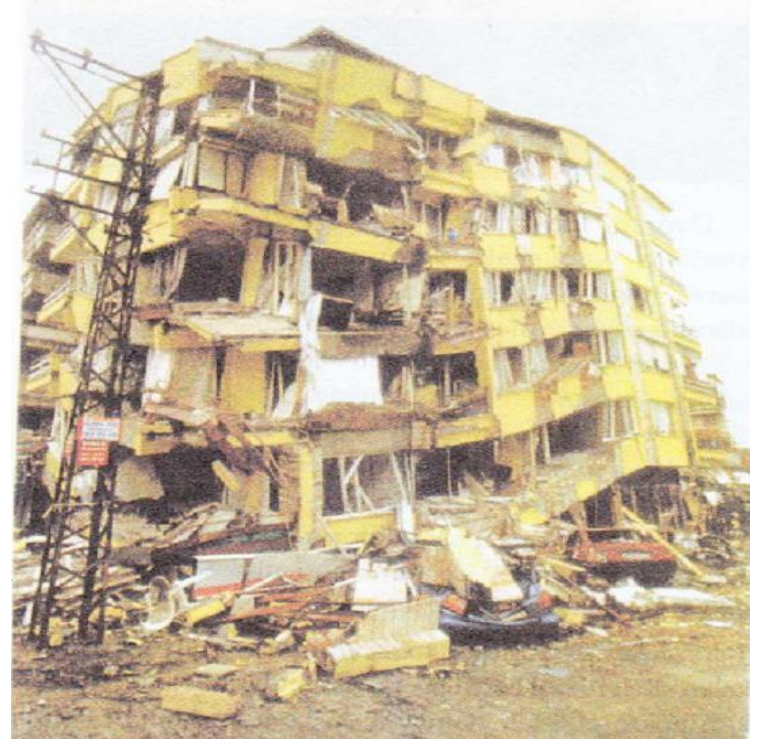

Şekil 39: Yatayda bir bölümün çökmesi hasarı (1999 Marmara)

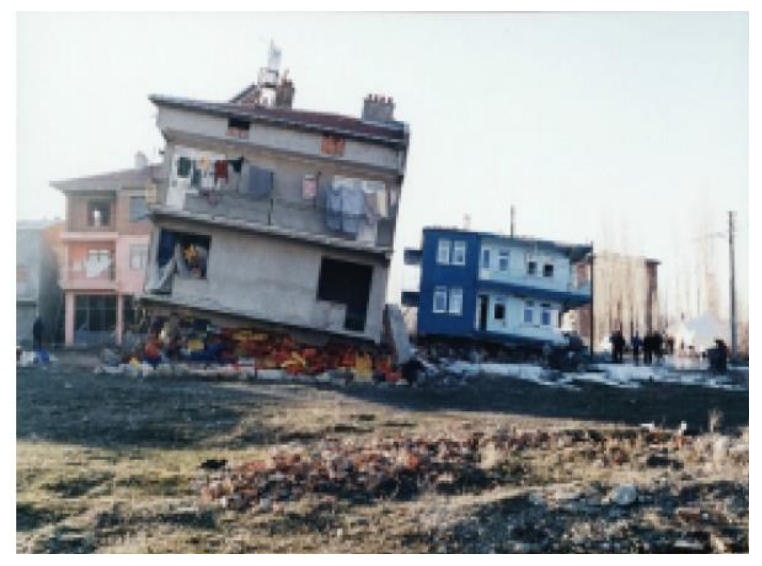

Şekil 41: Çay ilçesi, Bolvadin yolu üzerinde hasarlı binalar (2002 Afyon) (Damcı vd. 2002).

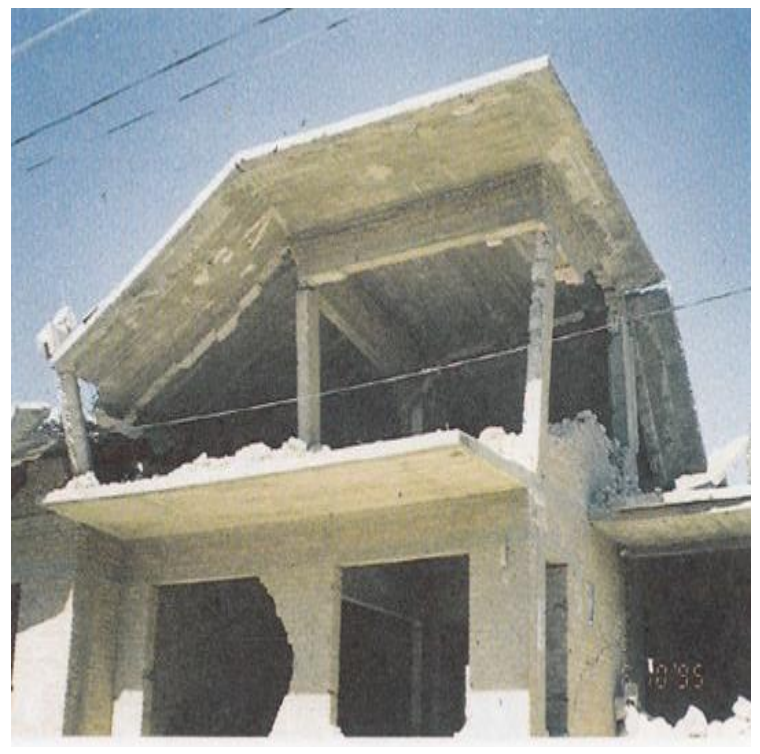

Şekil 40: Narin kolon nedeniyle düşeyde bir bölümün çökmesi hasarı (1999 Marmara)

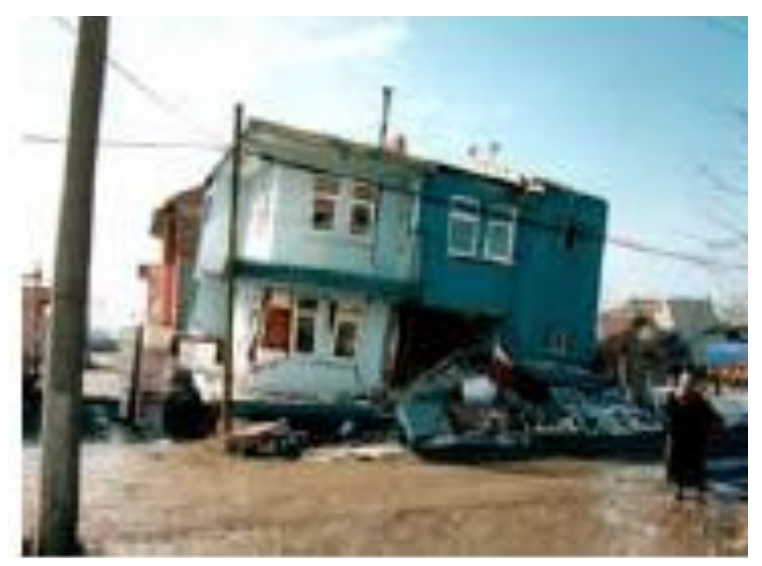

Şekil 42: Yatayda bir bölümün çökmesi hasarı (2002 Afyon) (Akıncıtürk 2003). 


\subsection{Yatayda Tam Kat Çökmesi}

Bu tip hasarlarda daha çok, narin alt kat kolonlarına fazla yük gelmesi sonucu kolonların kesme etkisiyle düzlem dışına kaydıkları görülmektedir. Kesmeye karşı koyamayan ilk nokta büyük ihtimalle sadece iki yönde kirişlerle desteklenmesinden dolayı Şekil 43'de görüldüğü gibi köşe kolonlarıdır. Bu tip yıkımlar, Şekil 44'de görüldüğü gibi kolon kiriş birleşim bölgelerinin iyi teşkil edilmeyişi sonucu düğüm noktası çözüşmelerinin sebep olduğu yıkımlardır (Karaşin ve Karaesmen 2005). Şekil 45-55'de bu sınıfa sokulabilecek hasar fotoğrafları sunulmuștur.

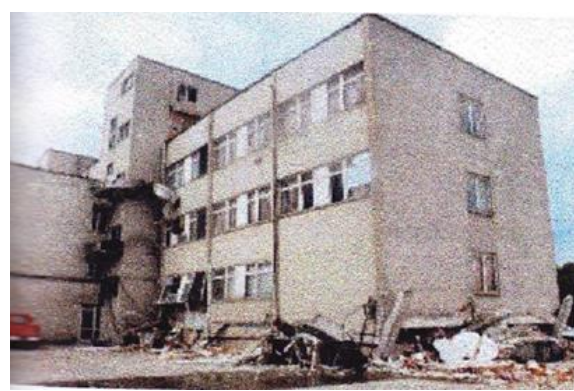

Şekil 43: Yatayda tam kat üstüne çökme (1999 Marmara).

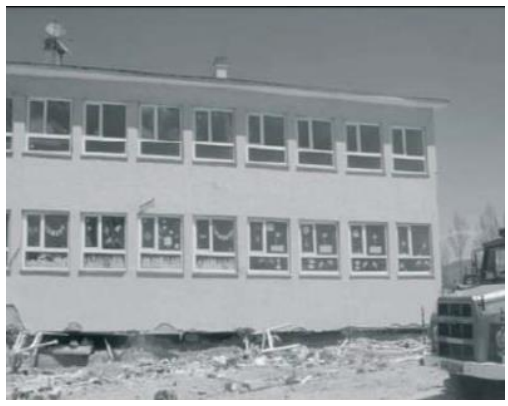

Şekil 45: Çeltiksuyu Illköğretim Okulu (2003 Bingöl)

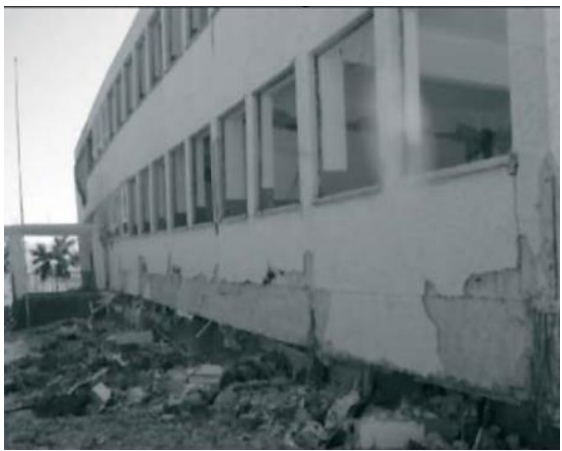

Şekil 47: Sarıçiçek Ilköğretim Okulu (2003 Bingöl)

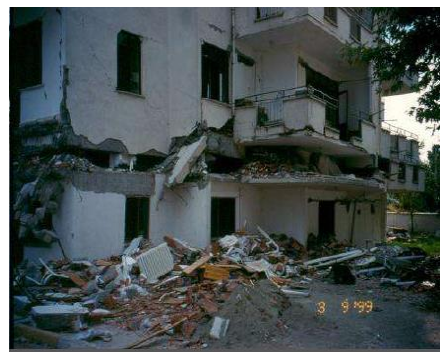

Şekil 49: 1999 Marmara (Akıncıtürk 2003)

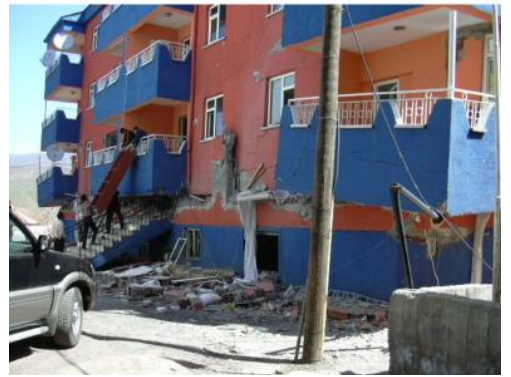

Şekil 44: Kolon- kiriş bölgesinde çözüşme (2003 Bingöl) (Karaşin ve Karaesmen 2005)

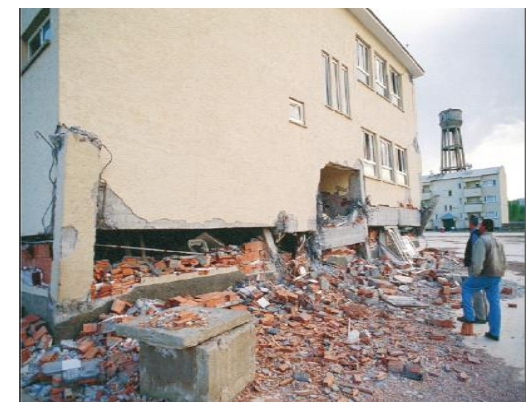

Şekil 46: Çeltiksuyu YİBO dershane binasının gördüğü hasara karşın, arka planda az hasarlı lojman binası ve hiç hasar görmeyen su deposu (2003 Bingöl) (Dirlik vd. 2003).

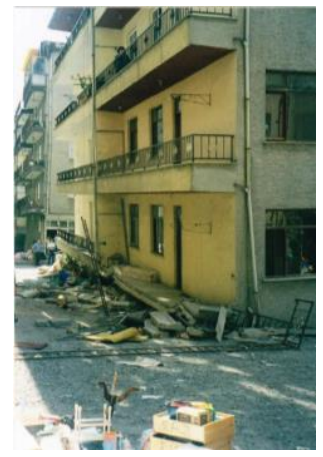

Şekil 48: Kocaeli'nde bir apartman (1999 Marmara)

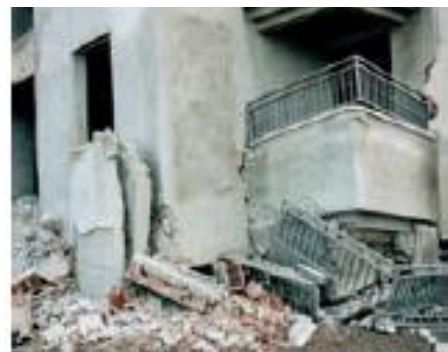

Şekil 50: Düzce depremi (Akıncıtürk 2003) 


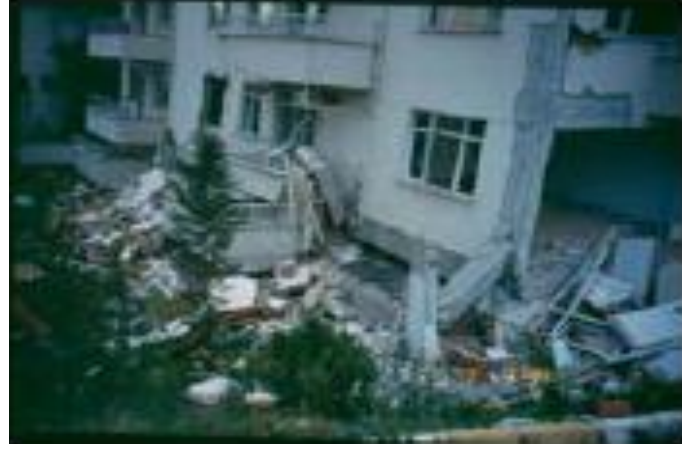

Şekil 51: 1999 Marmara depremi- Yalova (Akıncıtürk 2003)

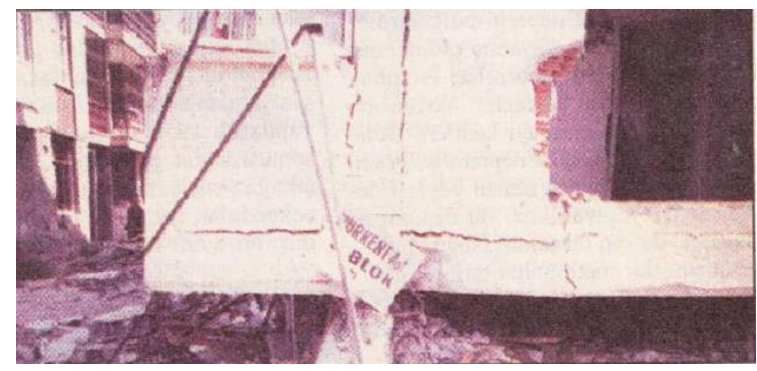

Şekil 53: 1999 Marmara

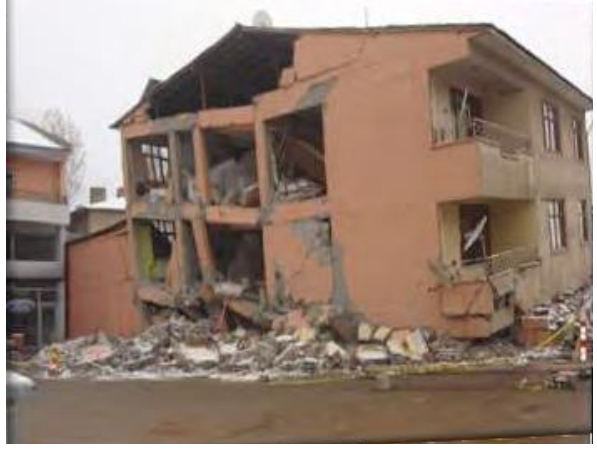

Şekil 52: 1999 Marmara (Nurlu 2012)

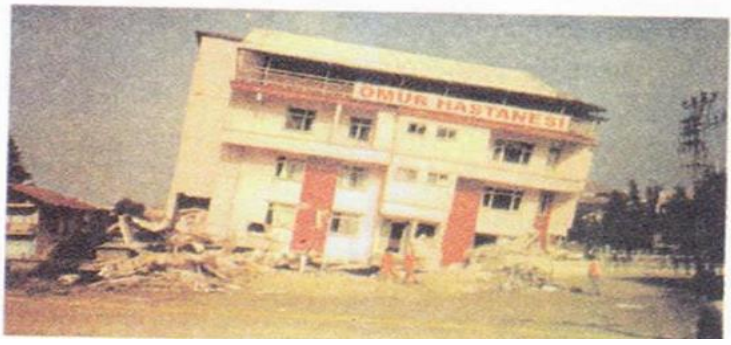

Şekil 54: Düzce'de bir özel hastane

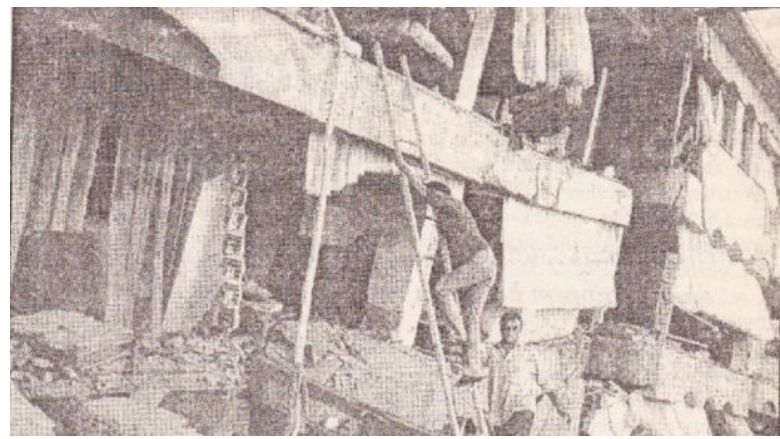

Şekil 55: 1999 Marmara

\section{Yapısal Eleman Hasar Türleri}

\subsection{Kolon Düzlem Dışı Sıyrılması}

1992 Erzincan depremi sonrası 4-5 katlı konut tipi bazı yapılarda özellikle zemin katlarda ortaya çıkan mekanizma durumları nedeniyle kolonların düzlem dışına itilmesi türünde hasarlar gözlenmiştir (Şekil 56, 57) (İTÜ 1992).

Alt kat kolonlarında plastik mafsallaşma, kolonların kesme etkisiyle düzlem dışına kayması, alttaki kirişlerin güçlü, kolonların zayıf olması, Şekil 58'deki sistemin alt katlardaki kolonlarda göçme mekanizmasıyla çökmesine neden olmuştur. Şekil 59'daki sistemde de, benzer fotoğraflarda olduğu gibi alt kolonlarda kesme etkisiyle düzlem dişına kayma görülmektedir. Kesme etkisi sonucu kolonların kirişlerden ayrılması üst kolonlarda da gözlenmektedir. Kolonlar yapıların asal taşıyıcı elemanlarıdır. Doğru projelendirilmiş ve doğru olarak uygulanmış yüksek olmayan bir binada, yatay rijitlik, sadece, uygun kesit boyutlarına ve donatıya sahip kolon elemanları ile sağlanabilir. Ancak, çoğu zaman yapım ve detaylandırma kurallarına yeterince uyulmaması ve mimari nedenlerle kolon kesit boyutlarının olabildiğince küçük tutulması gibi nedenlerle kolonlar deprem sırasında yeterli enerji tüketebilme kapasitesine sahip olamamaktadır. Şekil 60-64'de kolonları düzlem dışına sıyrılmış yapı örnekleri gösterilmiştir. Ülkemizde sıkça rastlanan kolon yerleşim ve detaylandırma hataları sonucunda, sadece kolonlar ile deprem kuvvetlerinin neden olacağı yatay yer değiştirmelerin yeterince önlenemediği gözlemlenmektedir. Sonuç olarak, yatay yer değiştirmelerin elastik sınırları aşması durumunda 
yapının komple veya kısmen göçmesi olasılığı artmaktadır. Örneğin, Şekil 65'de görülen kat kaybetmiş yapıda hiç deprem perdesi bulunmamaktadır. Duvarların içine saklanma kaygısı içindeki kolonların kesitleri de 20-25cm genişliktedir. Oldukça az donatı kullanılmış olduğu resimde de görülen bu elemanların deprem sırasında yeterli performans gösteremediği aşikardır. Yine de, yeterli oranda deprem perdesi yerleştirilmiş olması durumunda, bu binanın büyük olasılıklar depremi hafif veya orta hasarlı olarak atlatabileceği söylenebilir (Kubin 1999).

Van Yolu, Erciş Van arasındaki ulaşımı sağlayan, yoğun bir trafik oluşan, değer olarak ilçenin en değerli ve merkezi yoludur. Ticari değerinden dolayı yapıların alt katları genel olarak farklı maksatlarla ticarethane olarak kullanılmaktadır. Bu binaların alt katlarının dükkân olması ve dolgu duvarların kaldırılması yumuşak kat oluşumuna sebep olmuş, göreli kat deplasmanları sebebi ile alt katlarda hasar oluşmasına veya yapının tamamen göçmesine neden olmuştur. Bazı kolonlarda ileri derecede akstan kayma gözlenmektedir. Bu durum kalıp işçiliğinin oldukça kötü olduğu sonucunu vermektedir. Düşey aksı tutmayan kolon veya perdelerin beklenen performansı göstermesi çok zordur. Örneğin Şekil 66'da görülen yapıda, düğüm noktaları plastik mafsallaşmıştır. Uygun düğüm noktası tasarımı ve imalatı yapılamadığı için düğüm noktaları plastikleşmiştir. Ayrıca Van Yolu Caddesindeki çoğu yapı gibi alt katları dükkân olan yapıların bu bölgelerinde yumuşak kat oluşmuştur. Buna ek olarak kirişlerin kolonlar kadar güçlü olduğu, güçlü kolon-zayıf kiriş ilkesine aykırı tasarım yapıldığı görülmektedir (Alan vd. 2011).

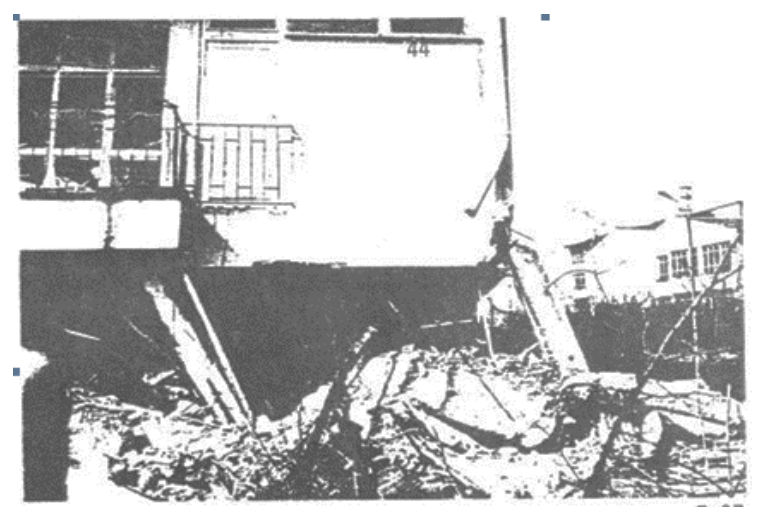

Şekil 56: Kolon sıyrılması hasarı (1992 Erzincan)

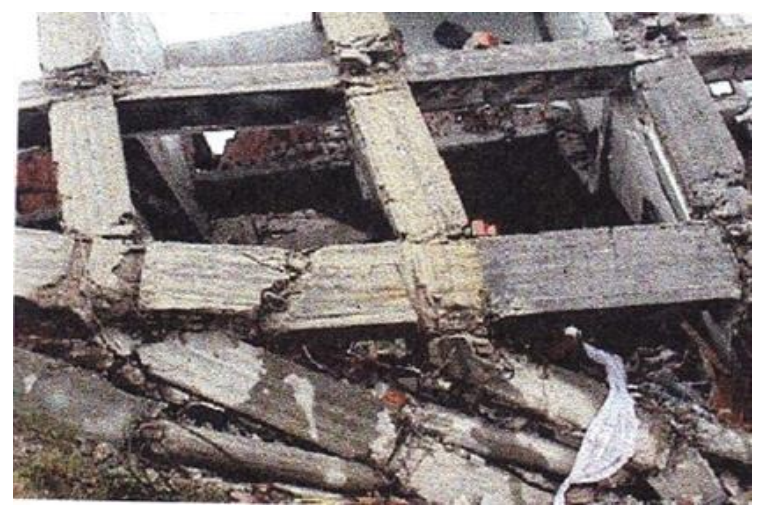

Şekil 58: 1999 Marmara

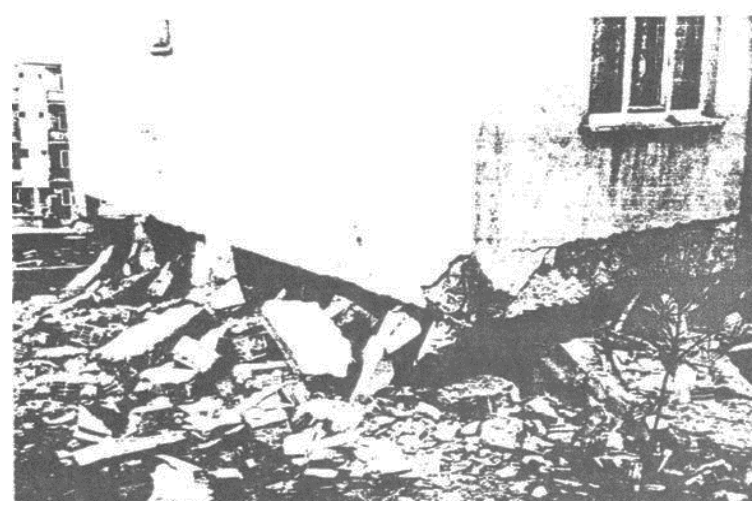

Şekil 57: Kolon sıyrılması hasarı (1992 Erzincan)

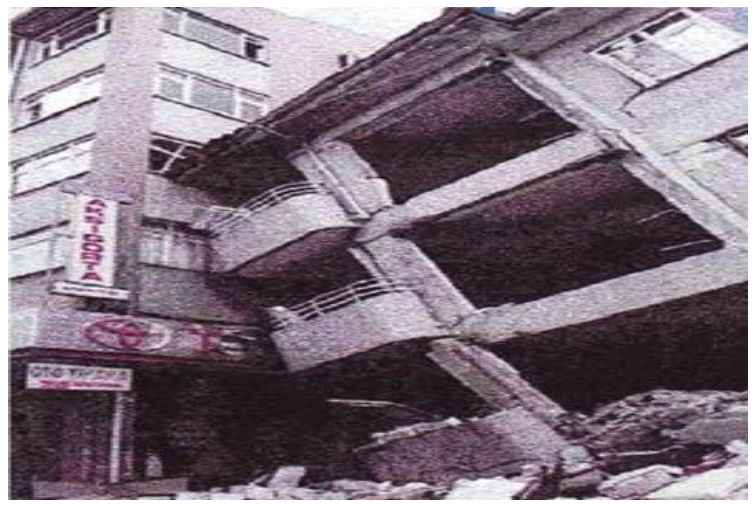

Şekil 59: 1999 Marmara 


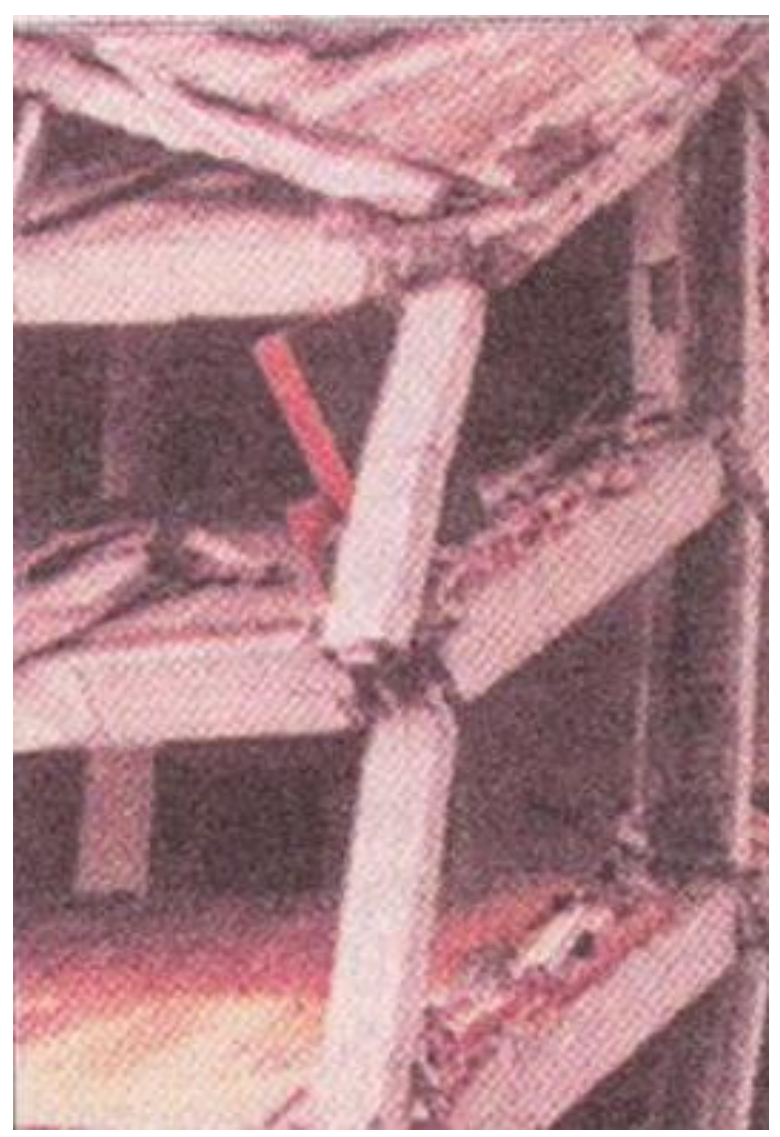

Şekil 60: 1999 Marmara

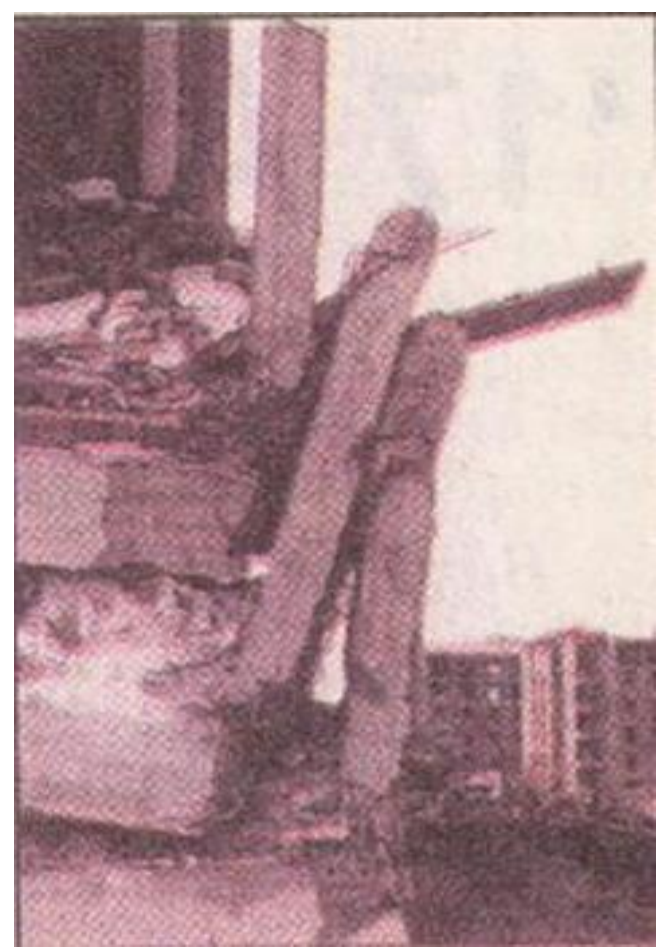

Şekil 62: 1999 Marmara

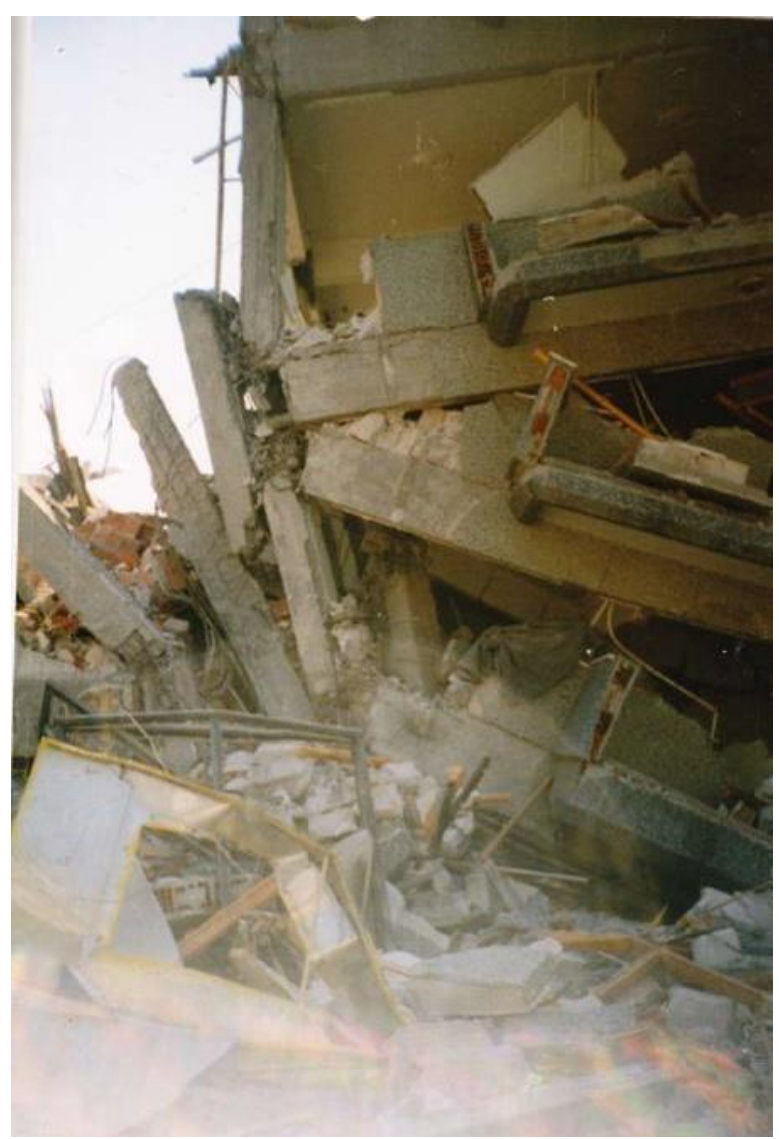

Şekil 61: 1999 Marmara

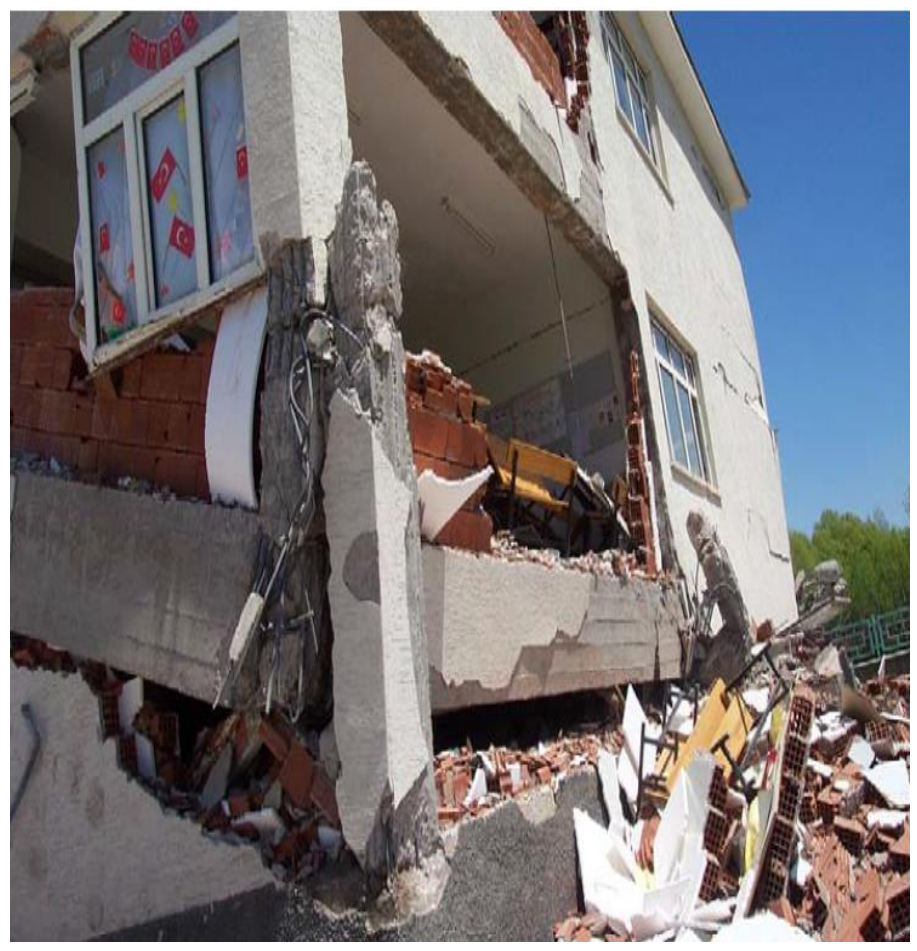

Şekil 63: Kolon kesmesi (2003 Bingöl) (Kalafat vd. 2003) 


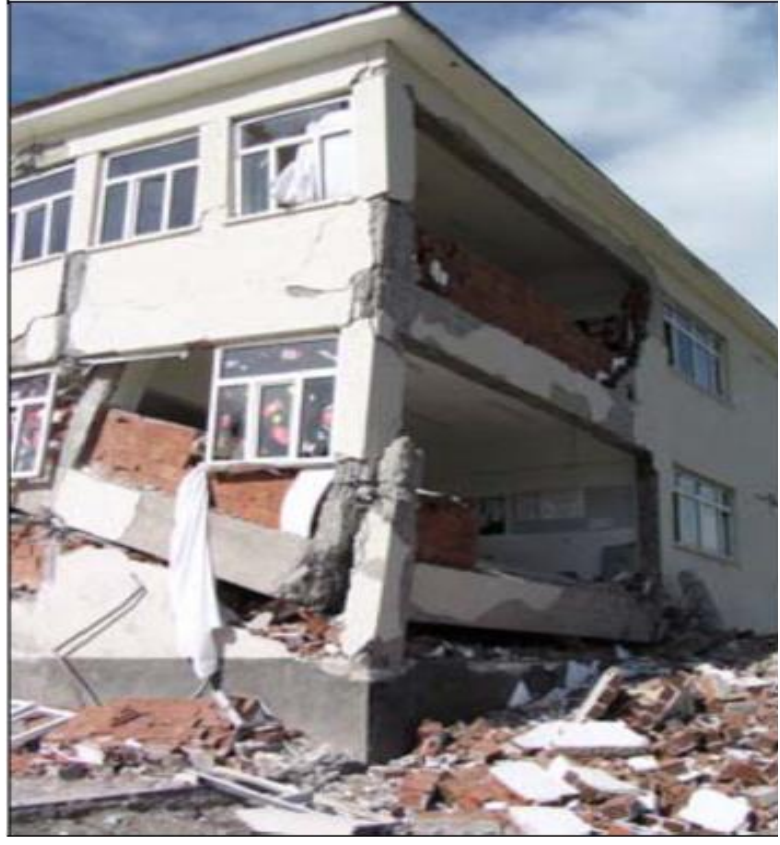

Şekil 64: 2003 Bingöl (İrfanoğlu 2009)

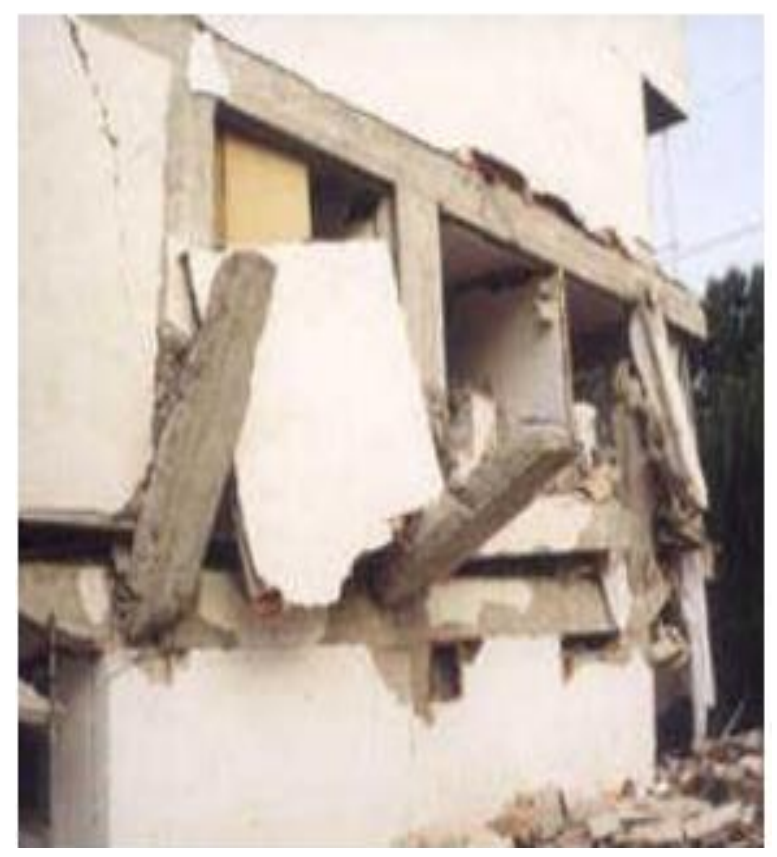

Şekil 65: 1999 Marmara (Kubin 1999)
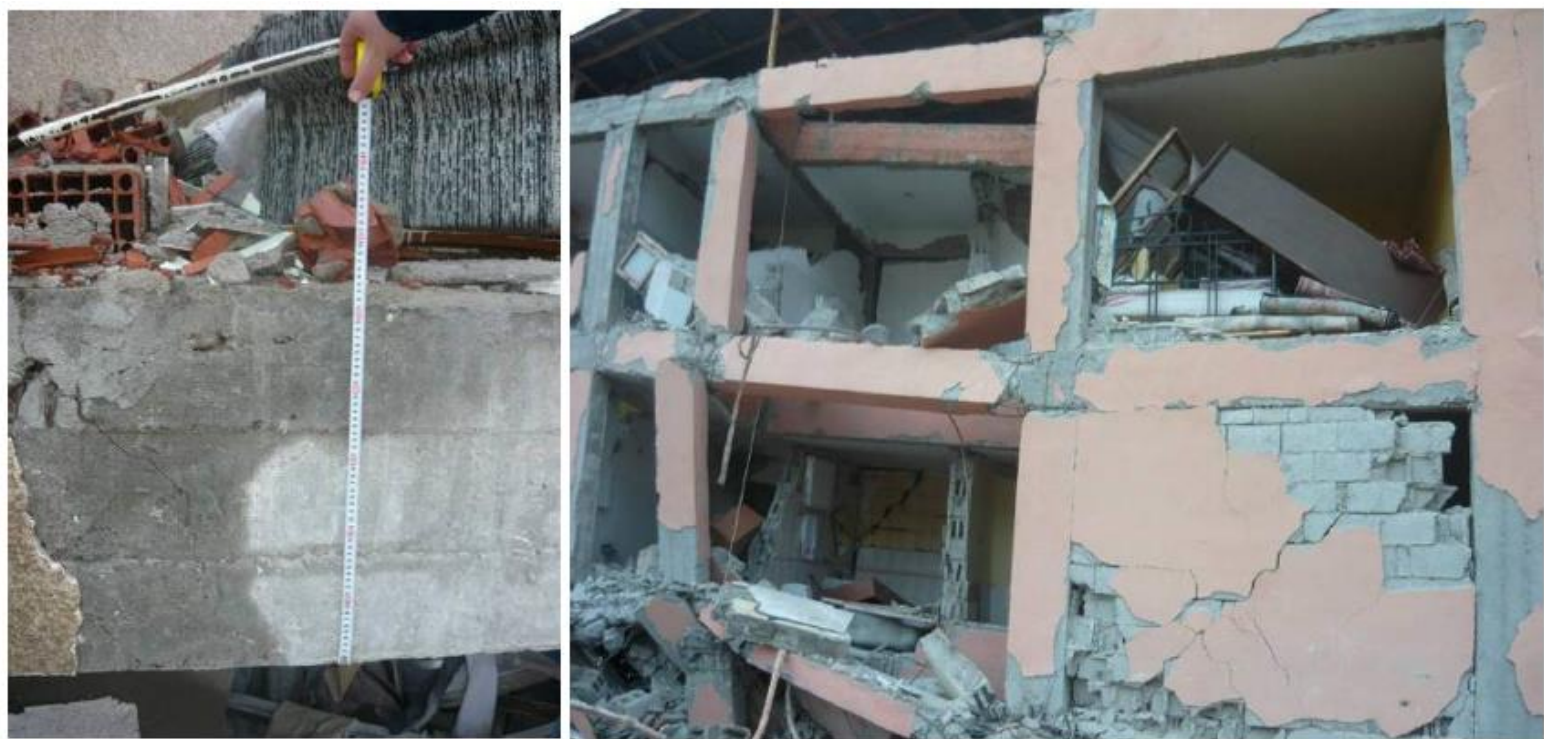

Şekil 66: Van Yolu Caddesinde yer alan ağır hasarlı yapı (Güney 2011)

\subsection{Kolon Uç Bölgesi Hasarı}

1992 Erzincan depremi sonrasında da hasarlı yapıların çoğunda, kolonlarda sarılma bölgesi donatılarının yetersiz olduğu, kolon boyuna donatılarının burkulduğu gözlenmiştir (Şekil 67) (İTÜ 1992). Kolon boyuna donatılarının konulma nedeni, yatay yükler altında kolonda oluşacak eğilme gerilmesinin yatay yükün yönüne göre kolon yüzeyinde oluşturacağı çekme gerilmelerini karşılamaktır. Deprem yatay yük etkisi her yönden gelebileceği için, kolonun tüm köşe ve gerekirse ek olarak yüzeylerine boyuna donatılar konulur. Ancak düşey basınç yüklerini taşımak amacıyla konulmamış kolon boyuna donatıları, betonun yetersizliği durumunda düşey yüklerle de zorlanmakta ya da yatay yükler altında etriye sıklaştırmasıyla burkulma boyları sınırlanmadığından ve yetersiz boyuna donatı konmasından, kolon boyuna donatıları burkulmaktadır. 1995 Dinar depremi sonrası hasar inceleme çalışmalarında, kolon uçlarında sargılanmış bölge oluşturan bir yapıya rastlanmadığı, kolon etriyelerinin çok yetersiz olduğu, basit dikdörtgen kesitli kolonlarda bile çiroz etriyeye rastlanmadığı kaydedilmiştir (Şekil 68). Yine aynı deprem sonrası yapılan incelemelerde, birçok hasarlı yapıda kolon sorunlarının ön planda göze çarptığı, birçoğunda kesme kırılması, birçoğunda mafsallaşma, bazılarında kesme/ eğilme etkileşmesi, birçoğunda donatı sıyrılması (yetersiz kenetlenme) görüldüğü, kirişlerde mafsallaşmaya yalnızca bir lise binası yapısında rastlandığı (Şekil 69), güçlü kiriş-zayıf kolon davranışının yaygın oluşu 
nedeniyle kirişlerde mafsallaşma yerine kolon hasarlarına rastlanmasının doğal karşılandığı raporlanmıştır. Örneğin aynı deprem sonrası hasarlarından bir örnek Şekil 70'de sunulmuştur. Şekilde kolona donatının yanlış yerleştirildiği, etriye sıklaştırılması yapılmadığı, bunun sonucu olarak da eğilme momenti etkisiyle düğüm noktalarına yakın yerlerde betonun daha çabuk çözüldüğü ve düşey donatının yerel burkulma yaptığı, TS500'ün donatı yerleştirmesiyle ilgili kurallarına uyulmadığı görülmektedir. Ayrıca Dinar depremi sırasında binaların yaş ortalamasının 25-30 arasında olduğu, kolon ve kiriş boyutlarının yürürlükteki yönetmeliklere uygun olmadığı, bazı binalarda bodrum katında kolonlarda ezilme veya deformasyon, kirişlerde moment ve kayma çatlakları görüldüğü belirtilmiştir (ODTÜ 1995).

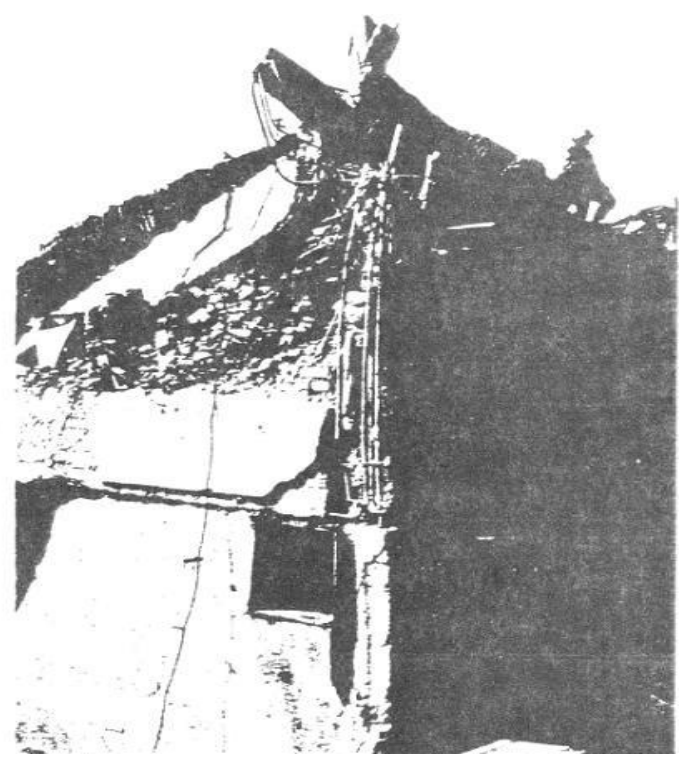

Şekil 67: Kolon etriye- boyuna donatı hasarı (1992, Erzincan) (ITÜ 1992).

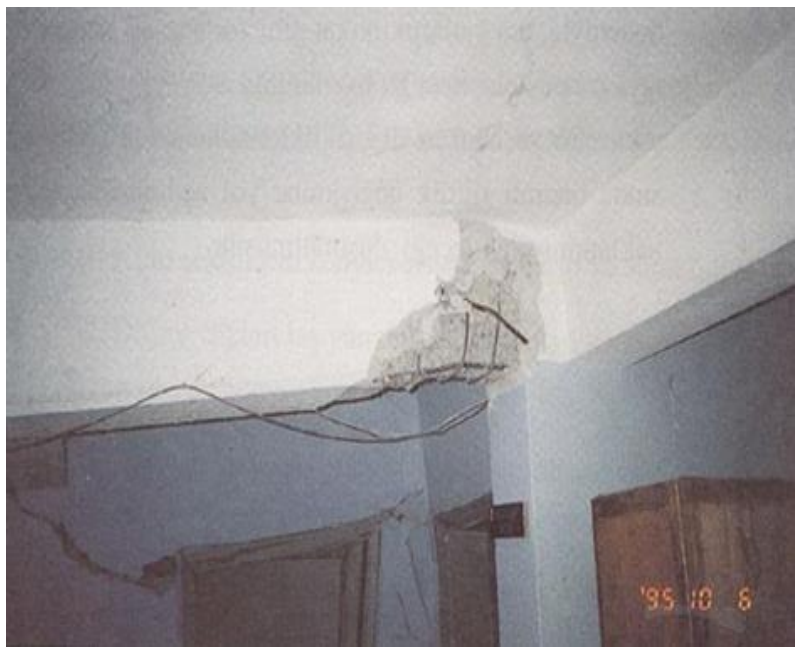

Şekil 69: Kirişte mafsallaşma örneği (Dinar lisesi) (ODTÜ 1995)

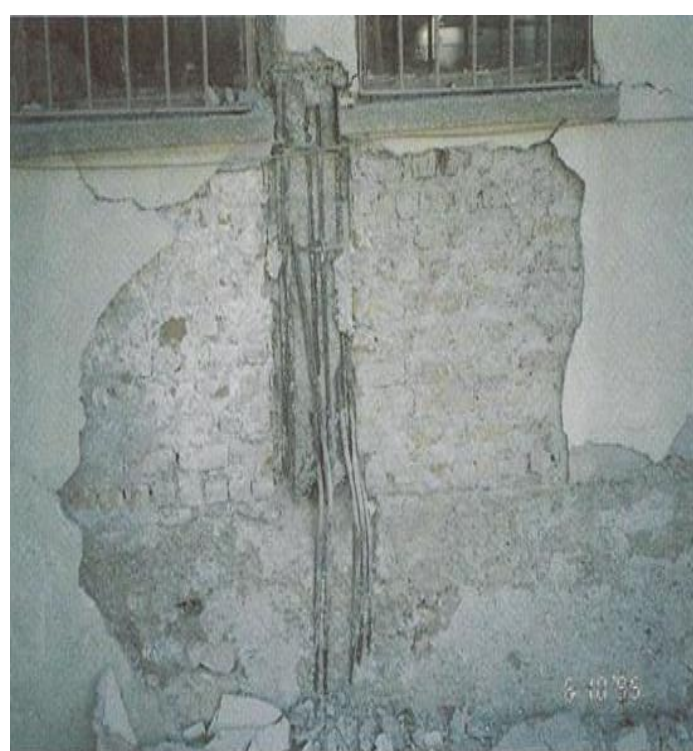

Şekil 68: Güçlü kiriş- zayıf kolon ve sargısız kolon örneği (195 Dinar) (ODTÜ 1995).

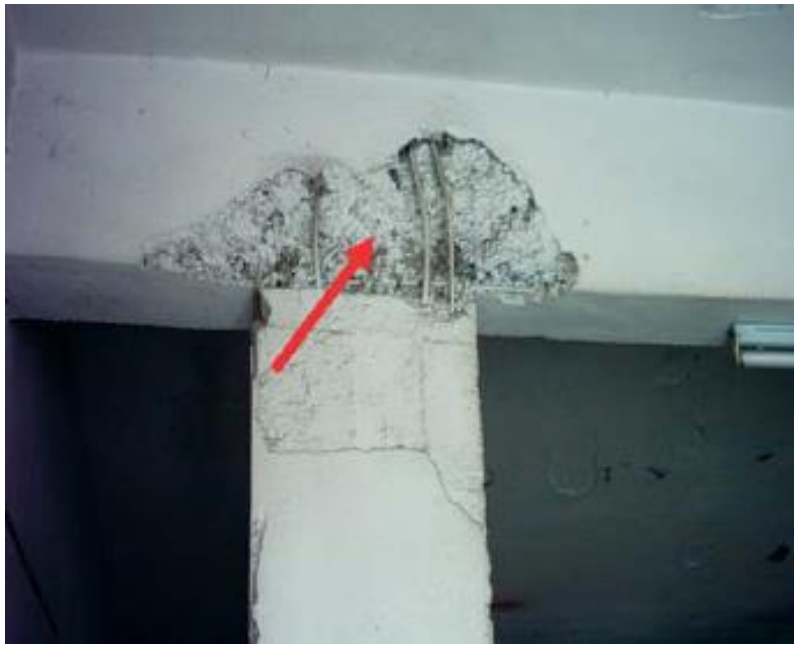

Şekil 70: Kolon- kiriş birleşim bölgesi hasarı örneği (1995 Dinar) (ODTÜ 1995)

Kısa kolon ve yumuşak kat problemleri analizlerde göz önüne alınmalıdır. Çok sık rastlanan yumuşak kat problemi, Şekil 71'de görülen, Çay ilçesi, sanayi çarşısındaki Cami'nin ağır hasar görmesine neden olmuştur. Şekil 71'de görülen Cami'nin köşe kolonu, yumuşak kat probleminin yanı sıra, kolon ve kiriş birleşimindeki donatı detay hatalarından dolayı kolonun mafsal hale gelmesine sebep olmuştur. Alt kat duvarlarını örmeden üst katları tamamlamanın deprem yükü altında yaratacağı problemler çok sık vurgulanmasına rağmen hata tekrarlanmıştır. Şekil 72'te Cami'nin iç kolonlarının hemen hepsi alt ve üst bağlantılarından mafsal hale gelmiş durumdadır. Tüm bu hasara rağmen binanın gerekli emniyete sahip olacak şekilde onarımı ve güçlendirilmesi mümkündür. Dolgu duvarlarının yapı rijitliğine etkisi göz ardı edilmemeli, olumlu ve olumsuz tüm etkileri analizlerde göz önüne alınmalıdır. Bu durumun olumlu etkisi Şekil 73 'te görülmektedir. Tuğla duvar kendisi hasar görerek binayı yıkılmaktan (ve belki de can kaybına neden olmaktan) kurtarmıştır. Detaylı hesaplar yapılmadan ve herhangi bir nedenle binayı emniyetsiz duruma düşürmeyeceği kanıtlanmadan yapıya asla müdahale edilmemelidir. Yapısal bir elemanı yok etmek bina için ne kadar hatalı ise, 
bilinçsizce ilave etmekte o kadar hatalıdır. Yapının duvarları dahil hiçbir elamanında aksi hesapla kanıtlanmadan değişiklik yapılmamalıdır. Örneğin simetrik davranışı bozacak bir duvar ilavesi bile sistemi emniyetsiz duruma düşürebilir (Damc1 vd. 2002). Bölgede tespit edilen tipik hasar örneklerinden biriside kolon uç bölgelerinde oluşan plastik mafsallaşmadır. Bu tip hasarlarla, kimi yapıların özellikle bölme duvarı olmayan bölümlerinde, kolon uç bölgelerinde karşılaşılmaktadır (Şekil 74). Bu tip hasarlar bazen de hem dolgu duvarlarda hem de kolon uç bölgelerinde birlikte gözlemlenir (Şekil 75). Hasarlar özellikle kolonların hemen uçlarında aşırı hale gelebilir (Şekil 76).
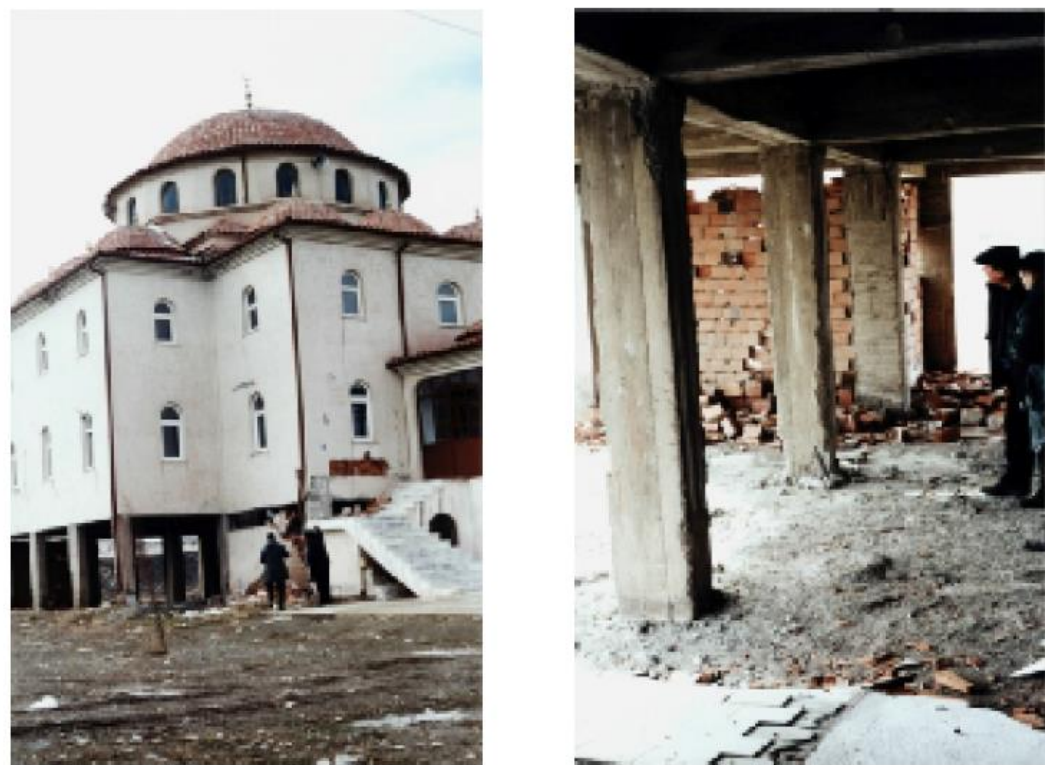

Şekil 71:Sanayi Çarşısında yapımı tamamlanmamış cami (Damcı vd. 2002)

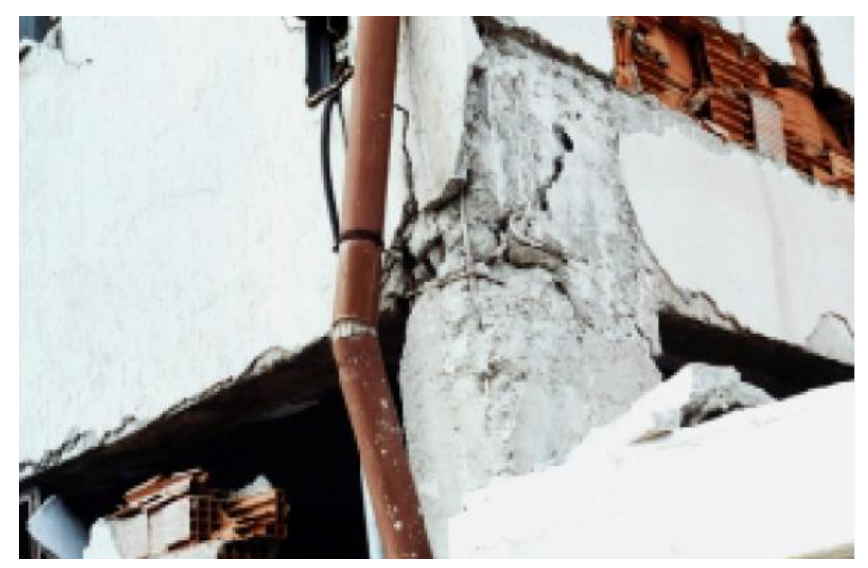

Şekil 72: Caminin mafsallaşmış kolon- kiriş birleşimi (Damcı vd. 2002).

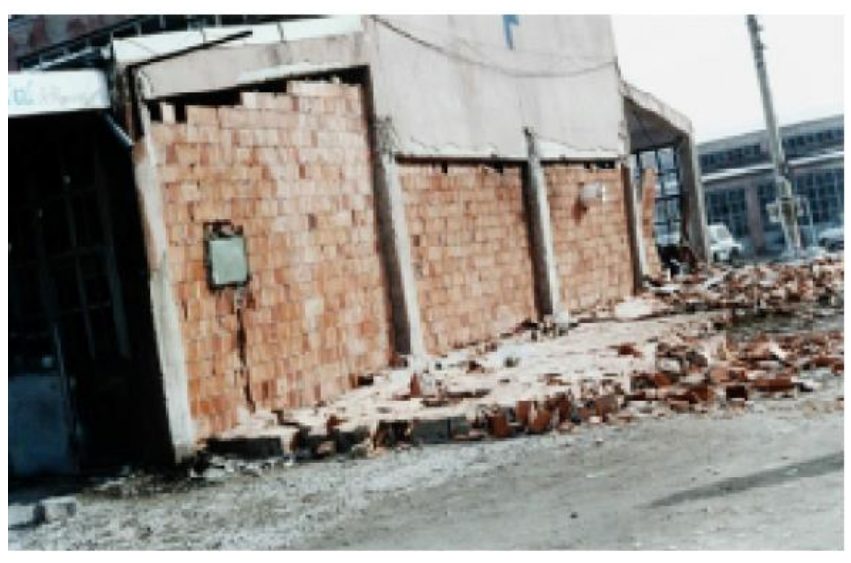

Şekil 73: Tuğla duvarları yıkılmış bir bina (Sanayi Çarşısı) (Damcl vd. 2002). 

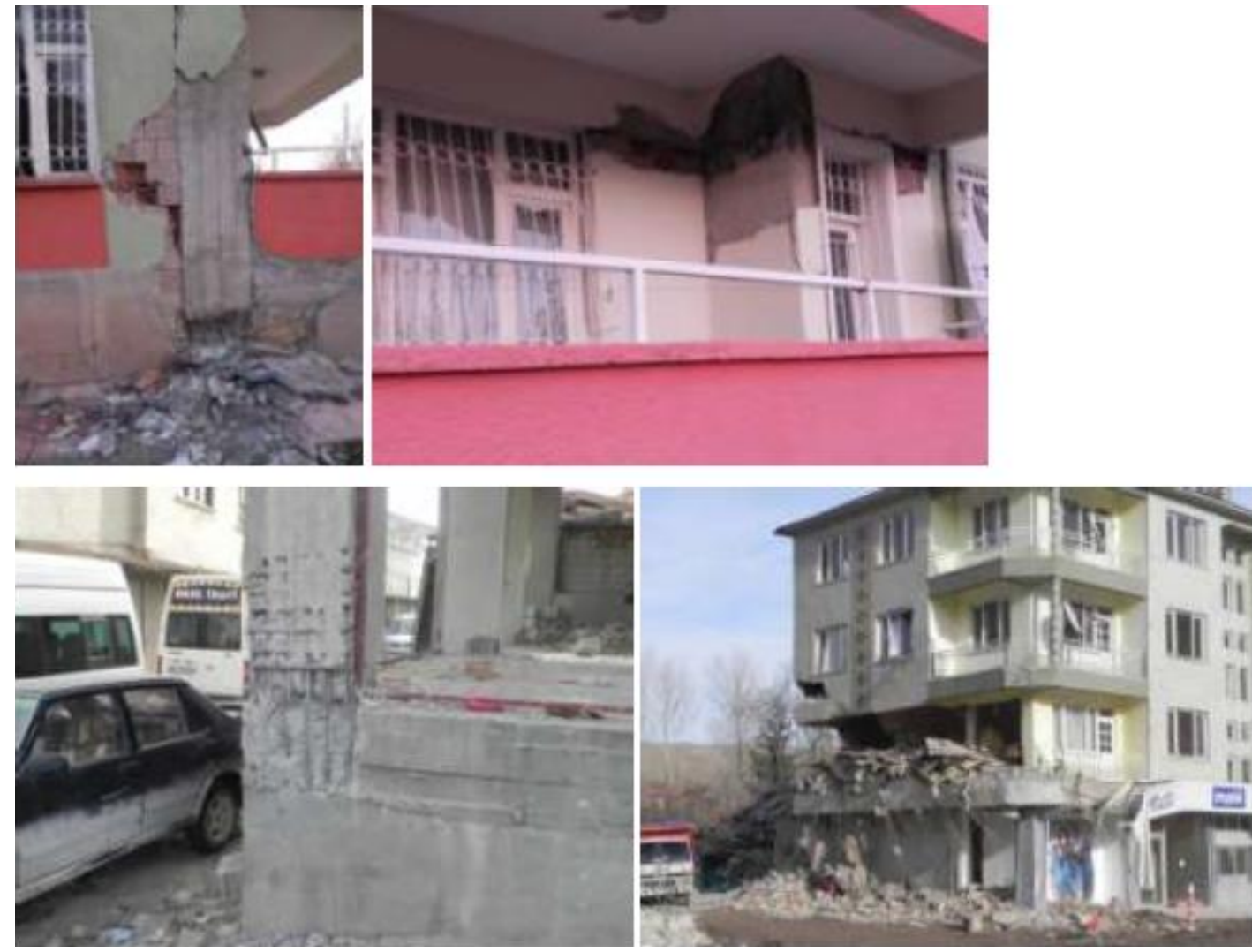

Şekil 74: Kolon uç bölgelerinde plastik mafsal oluşumu (Karancı vd. 2011)

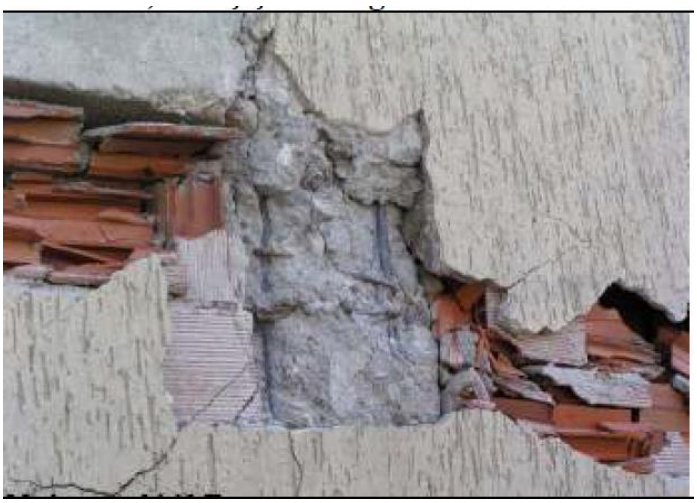

Şekil 75: M. Akif Illköğretim Okulu

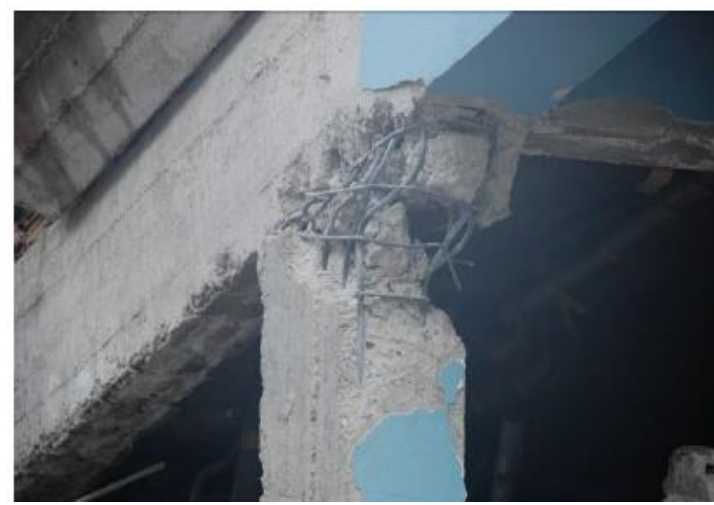

Şekil 76: Van Depremi (Güney 2011)

\section{Sonuçlar ve Öneriler}

Depremler sonrası görülen özellikle kolon ve kolon-kiriş birleşim bölgesi hasarları kaynaklı ağır betonarme yapı hasarlarını azaltmak için uyulması gereken bazı temel ilkeler şu şekilde verilebilir:

1) Plastik mafsallar kiriş uçlarında oluşacak şekilde sistem tasarımı oluşturulmalı, bunun için de kirişler sı̆̆ yapılmalı, kolon kesitleri büyütülmelidir.

2) Asmolen yapılarda yatay ötelenmeler daha fazla olacağından bu yatay ötelenmeyi karşılamak için her iki yönde perde kolonlar yerleştirilmelidir.

3) Narin kolon oluşumundan kaçınmalıdır. Kolon kesit boyutları en azından yönetmelik minimum şartlarına uygun olmalıdır.

4) Kolonlar mümkün mertebe her taraftan kirişlerle desteklenmeli, düzlem dışına çıkmalarını önleyecek tedbirler alınmalıdır.

5) Kolon kiriş birleşimlerinde etriye sıklaş̧ırılması yapılmalı, kesişimin kolon kısmında etriyeler mutlaka devam ettirilmelidir.

6) Kolon boyuna donatılarının düşey yükleri taşımak amacıyla konulmadığı mutlaka akılda tutulmalıdır. Yatay yüklerin oluşturacağı eğilme etkilerinde meydana gelecek çekme kuvvetlerini taşımak amacıyla konulan kolon boyuna 
donatıları, betonun kesit ve/veya malzeme bakımından yetersizliği durumunda düşey yüklerle de zorlanmaktadır. Ayrıca yatay yükler altında, etriye sıklaştırmasıyla burkulma boyları da sınırlanmadığında ve/veya yetersiz boyuna donatı konulduğunda kolon boyuna donatıları burkulmaktadır. Tüm bu durumlara önemle dikkat edilmelidir.

7) Kısa kolon ve yumuşak kat problemleri analizlerde göz önüne alınmalıdır. Dolgu duvarlarının yapı rijitliğine etkisi göz ardı edilmemeli, olumlu ve olumsuz tüm etkileri analizlere yansitılmalıdır. Yapısal bir elemanı yok etmek bina için ne kadar hatalı ise, bilinçsizce ilave etmekte o kadar hatalıdır. Yapının duvarları dahil hiçbir elamanında aksi hesapla kanıtlanmadan değişiklik yapılmamalıdır. Örneğin simetrik davranışı bozacak bir duvar ilavesi bile sistemi emniyetsiz duruma düşürebilir.

8) Zayıf kolonla aynı etkiyi doğurabilecek kat çıkmalarının, konsol kiriş- döşemelere taşıtılmış olmasının ve geniş ve uzun balkonların yapılmış olmasının da yıkımı kolaylaştırıcı etkenler olduğu iyi bilinmeli ve bu tür yapı yapılmak istendiğinde sağlam zemin şartı aranmalı ve/veya özel projelendirme ve imalat yapılmalıdır.

9) Yapılarda en kolay hasar görebilecek bölüm, genelde, burulmanın da etkisiyle, aynı zamanda dört yönde kiriş desteğinden de mahrum kalan köşe kolonları civarıdır. Dolayısıyla özellikle yapı köşe bölgelerinde tasarımdan imalata tüm kurallara sıkı sıkıya riayet etmenin önemi büyüktür. Bu yapılmaz ve aksine güçlü kiriş-zayıf kolon, narin yüksek kolon, bölme duvar desteğinin kaldırılması, kolon etriyelerinin sıklaştırılmaması, beton yerleşim ve kalitesine dikkat edilmemesi, yüksek giriş ve konsol çıkma gibi hatalar bu bölgelerde yoğunlaştırılmış olursa ve sistem bütününde de yatay yükler altında oluşabilecek burulma etkilerini azaltıcı düşey rijit taşıyıcı dağılımına dikkat edilmezse, hasarlar kaçınılmaz olmaktadır.

10) Özellikle temel üstünde, alttaki kirişlerin güçlü, kolonların zayıf olması, sistemin alt katlardaki kolonlarda plastik mafsallaşmayla göçme mekanizmasına uğramasına ya da alt kolon altlarında kesme etkisiyle düzlem dışına kaymaya neden olabilir. Böyle durumların oluşabileceği hallerde dengeli bir perde duvar desteği şarttır.

11) Türkiye'de sıkça rastlanan kolon yerleşim ve detaylandırma hataları sonucunda, sadece kolonlar ile deprem kuvvetlerinin neden olacağı yatay yer değiştirmelerin yeterince önlenemediği gözlemlenmektedir. Bu nedenle tüm betonarme yapıların perde- çerçeve sistemli ya da en azından geniş kolon destekli yapılma zorunluluğu getirilmelidir.

12) Türkiye koşullarında ne yazık ki, bazı kolonlarda ileri derecede akstan kayma gözlenmektedir. Bu durum kalıp işçiliğinin oldukça kötü olduğu gösterir. Düşey aksı tutmayan kolon veya perdelerin beklenen performansı göstermesi çok zordur. Düğüm noktalarında plastik mafsallaşma çok kolay oluşur. Kalıp işçiliğine özellikle dikkat edilmesi ve denetlenmesi gerekmektedir.

13) Davranış bilgisi ve donatı detaylandırma ilke ve sebepleri, basit düzeyde ve anlaşılabilecek bir şekilde işçisinden ustasına tüm inşaat saha personeline verilmelidir. Örneğin etriyenin fiziksel işlevi işçilere basit bir şekilde anlatılırsa etriye kancasının özensiz yapılması durumlarının azalacağını tahmin etmek güç değildir.

14) Yapıların fiziksel davranış bilgisi proje ve saha mühendislerince ve özellikle mimarlarca çok iyi bilinmeli, bina davranışı detaylı analizler sonucunda belirlenmeli ve proje ve uygulamalar buna göre yapılmalıdır.

15) Mevcut yapıların performanslarının belirlenmesine yönelik olarak da, şu söylenebilir: Deprem yönetmeliği 2007 yılında yenilendiğinde (TMMOB 2007) 1998 yılındaki yönetmelikte (TMMOB 1998) eksik olan mevcut yapıların deprem performansının incelenmesi konusu da yönetmeliğe dahil edilmiştir. Buna da bağlı olarak, kolon ve kolon kiriş birleşimi bölgelerinin de incelenen yapılarda her yönden (malzeme, donatı, geometri) dikkatle araştırılması büyük önem taşımaktadır.

\section{Kaynaklar}

Akıncitürk N.,(2003), Yapı tasarımında mimarın deprem bilinci, Uludă̆ Üniversitesi Mühendislik-Mimarlık Fakültesi Dergisi, 8(1), 189-201.

Alan H., Bozkurt E., Çağlayan D., Dirlik K., Özkaymak Ç., Sözbilir H., Topal T., (2011), Van Depremleri (Tabanll- Edremit) Raporu, TMMOB Jeoloji Mühendisleri Odası, Yayın no:110, Ankara, 60ss.

Bayulke N., Kocaman C., Koksal T.S., Kuran F., (2004), 1 Mayıs 2003 Bingöl Deprem Raporu, Rapor No: 5149-1, Afet İşleri Genel Müdürlügü, Deprem Araştırma Dairesi Deprem Mühendisliği Şubesi, Ankara, 36ss.

Büyükkaragöz A., (2007), Zaylf kolon ve güçlü kiriş birleşimlerinin deneysel olarak incelenmesi, Furat üniversitesi Fen ve Mühendislik Bilimleri Dergisi, 19(4), 553-560.

Çaydemir B., (2012), Betonarme Yapı Tasarımı Dersi, http://www.yildiz.edu.tr/ caydemir/betprj/Kolonbetonarme.pdf [Erișim 2 Temmuz 2014].

Damcı E., Öztorun N.K., Çelik T., Çoşgun T., (2002), Afyon Depremi ile ilgili Görüşler, ECAS2002 Uluslararası Yap1 ve Deprem Mühendisliği Sempozyumu, 14 Ekim, ODTÜ, Ankara.

Dirik K., Yürür T., Demirbağ H., (2003), 1 Mayls 2003 Çimenli (Bingöl) Depremi Değerlendirme Raporu, Hacettepe Üniversitesi Mühendislik Fakültesi Jeoloji Mühendisliği Bölümü, Ankara, 42ss.

Gümüşçü M., Özcan N., Kaya N., (2004), Şanlıurfa'daki betonarme yapıların mevcut durumu, Türkiye Mühendislik Haberleri, 434 2004/6, 41-48.

Güney D.,(2011), 23 Ekim 2011 Van Depremi Teknik Inceleme Raporu, Y1ldız Teknik Üniversitesi, İstanbul, 66ss.

İrfanoglu A., (2009), Performance of Template School Buildings during Earthquakes in Turkey and Peru, Journal of performance of constructed facilities, 23(1), 5-14.

İTÜ, (1992), 13 Mart 1992 Erzincan Depremi Hakkında Rapor I, İTÜ Yapı ve Deprem Uygulama-Araştırma Merkezi, İstanbul, 24ss.

Kalafat D., Güneş Y., Arpat E., Ölmez Y., Öz G., Horasan G., Kekovalı K., Öğütçü Z., Püskülcü S., Yılmazer M., Köseoğlu A., Berberoğlu A., Kılıçer F., Kara M., Güngör A., Görgün E., Gömeç A., Gümüş H., Berberoğlu M., Deniz P., Kafade N., Suvarıklı 
M., (2003), 1 Mayls 2003 Bingöl Depremi Ön Raporu, Boğaziçi Üniversitesi Kandilli Rasathanesi ve Deprem Araştırma Enstitüsü Sismoloji Servisi, 58ss.

Karancı A.N., Kalaycıŏglu S., Erkan B.B.B., Özden A.T., Çalışkan İ, Özakşehir G., (2011), Tabanlı-Van (23 Ekim 2011) ve EdremitVan (9 Kasim 2011) Depremleri İnceleme Raporu, ODTÜ, Ankara, 28ss.

Karaşin A., (2003), 2003 Bingöl Depremi Işı̆̆ında Betonarme Binaların Depremsel Davranışına Toplu Bir Bakış, 5. UlusalUluslararası Deprem Mühendisliği Kongresi, İstanbul.

Karaşin A.H., Karaesmen E., (2005), Bingöl Depreminde Meydana Gelen Yapısal Hasarların Irdelenmesi, Deprem Sempozyumu, Kocaeli.

Koçyiğit A., Bozkurt E., Kaymakcı N., Şaroğlu F., (2002), 3 Şubat 2002 Çay (Afyon) Depreminin Kaynă̆l ve Ağır Hasarın Nedenleri: Akşehir Fay Zonu (Jeolojik ön Rapor), ODTÜ Müh. Fak. Jeoloji Müh. Böl. Tektonik Araştırma Birimi, 36ss.

Kubin J., (1999), Tipik Deprem Hasarlarl ve Nedenleri, ODTU, Sanal Gazete, Y11 4, Say1 4, Ankara.

Nurlu M. (2012), Van depreminden ögrendiklerimiz, Deprem zararlarının azaltılması semineri, AFAD, Ankara.

ODTÜ, (1995), 1 Ekim 1995 Dinar depremi mühendislik raporu, ODTÜ İnşaat Mühendisliği Bölümü Deprem Araştırma Merkezi ve TMMOB İnşaat Mühendisleri Odası Ankara Şubesi, Ankara, 62ss.

TMMOB, (1998), Afet Bölgelerinde Yapılacak Yapılar Hakkında Yönetmelik, TMMOB İnşaat Mühendisleri Odası İzmir Şubesi, İzmir, $85 \mathrm{ss}$

TMMOB, (2007), Deprem Bölgelerinde Yapılacak Binalar Hakkında Yönetmelik, TMMOB İnşaat Mühendisleri Odası İstanbul Şubesi, İstanbul, 166ss. 